\title{
CELLULOLYTIC MICROORGANISMS: DIVERSITY AND ROLE IN CONVERSION OF RICE STRAW TO BIOETHANOL
}

\author{
PARDEEP KAUR, ${ }^{*}$ MONICA SACHDEVA TAGGAR ${ }^{* *}$ and JASPREET KAUR ${ }^{* * *}$ \\ *Department of Biotechnology, Sri Guru Granth Sahib World University, \\ Fatehgarh Sahib-140406, India \\ ** Department of Renewable Energy Engineering, Punjab Agricultural University, \\ Ludhiana-141004, India \\ *** Department of Biochemistry, Punjab Agricultural University, Ludhiana-141004, India \\ $₫$ Corresponding author: P. Kaur, pardeepkaur2108@gmail.com
}

Received December 25, 2019

Lignocellulosic biomass is considered to be an inexhaustible biopolymer known to mankind. For the successful exploitation of lignocellulosic biomass, such as rice straw, as a substrate for the production of industrially significant value-added products, such as bioethanol, its conversion into fermentable sugars, sugar acids and phenolics is the most imperative step. Enzymatic hydrolysis of lignocelluloses is performed by cellulases, a complex enzyme system comprising endo-1,4- $\beta$-D-glucanase, exo-1,4- $\beta$-D-glucanase and $\beta$-D-glucosidase. Cellulases are produced by a diverse range of microorganisms, including bacteria, fungi, actinomycetes, algae, insects and mollusks. However, the cost of cellulase is a major economic barrier for ethanol production. To economize the ethanol production process for its successful utilization at the industrial scale, genetic improvement of microorganisms, and other industrially relevant strategies of enzyme production and recycling need to be adopted.

Keywords: lignocellulose, rice straw, cellulases, hydrolysis, bioethanol

\section{INTRODUCTION}

A spurt in industrialization, booming population growth, injudicious utilization of natural resources over the past few decades have compelled us to exploit alternative renewable energy resources to meet the upsurging energy demands. ${ }^{1}$ Lignocellulosic biomass like rice straw is a widely available, cheap, polymeric, renewable resource and has attracted wide interest in the search of alternative ways to meet future energy demands. The chemical composition of rice straw, with $32-47 \%$ cellulose, $19-27 \%$ hemicelluloses and 5-24\% lignin, makes it an ideal substrate for ethanolic fermentation. ${ }^{2}$ Complete and efficient hydrolysis of cellulose requires an enzyme complex called cellulase enzyme complex, involving the synergistic action of different enzymes, viz. exo-glucanases, endoglucanases and $\beta$-glucosidase. Cellulases belong to the glycoside hydrolase family of enzymes and act by cleaving $\beta, 1-4$ glycosidic bonds of polysaccharides and oligosaccharides. ${ }^{3}$ Cellulases are produced by diverse types of microorganisms, including bacteria, fungi, actinomycetes, algae, insects and mollusks. However, the major impediment in the successful commercialization of cellulase is its exorbitant cost. ${ }^{4} \mathrm{~A}$ wide array of strategies, such as the isolation of potential cellulase producing microorganisms, use of low-cost substrates, such as rice bran, rice straw, wheat bran, coconut coir pith etc., and solid substrate fermentation as a mode of enzyme production, improved cellulase synthesis by genetic engineering, ${ }^{5}$ and recycling of cellulase by immobilization, ${ }^{6,7}$ could appreciably bring down the cost of the saccharification process. The present review synthesizes available information on cellulose, its structure and the historical background of its research, as well as on cellulase complexes, their structure and catalytic mechanisms, the microbial sources of cellulases and their role in the conversion of lignocellulosic biomass (rice straw) to ethanol. Also, the review discusses some challenges in the way of ethanol production and proposes future research directions. 


\section{CELLULOSE - FUNDAMENTAL ASPECTS AND HISTORICAL BACKGROUND}

Cellulose is known to be the most abundant and almost inexhaustible biopolymer. As per estimations, $10^{11}-10^{12}$ tons of cellulose is synthesized annually through photosynthesis, either in pure form or in combination with lignin and other polysaccharides, such as hemicelluloses. The trend towards these kinds of resources and their customization to obtain novel products to be used for the welfare of mankind has led to a resurgence of integrative cellulose research and an immense interest in using this biopolymer. ${ }^{8}$ Cellulose as a polymeric raw material has been used for a wide variety of purposes for centuries, e.g. for the production of paper products, such as cotton, rayon and linen for clothes. Cellulose also acts as a precursor for many chemical conversions involved in the production of stable cellulose derivatives, e.g. nitrocellulose for explosives and cellulose acetate for films. The name ${ }^{\mathrm{TM}}$ cellulose was coined by Payen, as early as in 1838, who was the first to recognize it as a definitive substance. ${ }^{9}$ Important landmarks in the field of cellulose research were the discovery of cellulose nitrate by Schönbein, ${ }^{10}$ Schweizer's reagent (cuprammonium hydroxide solution) as the first cellulose solvent in 1857 (Schweizer, 1856, 1857, 1859), ${ }^{11-13}$ and cellulose acetate synthesis. ${ }^{14-15}$ The fundamental experiments of Staudinger ${ }^{16-17}$ on the acetylation and deacetylation of cellulose led to the evolution of cellulose chemistry as a branch of polymer research. ${ }^{18}$

\section{Diversity of cellulose}

Cellulose is derived from lignocellulosic materials, such as agricultural residues, plant fibers, grasses and wood. ${ }^{19}$ Lignocellulosic biomass is primarily composed of cellulose, hemicellulose, and lignin, the composition of which may vary depending on the type of biomass, e.g. corn stover, straw, wheat straw, algae and others (Table 1). Cellulose is synthesized by a multitude of microorganisms, bacterial species, e.g., Acetobacter, Rhizobium and Agrobacterium. ${ }^{20}$ Besides, some pathogenic bacteria have also been found to synthesize cellulose. Cyanobacteria, which represent the most primitive forms of life on the earth, also synthesize cellulose. ${ }^{21}$ Eukaryotic organisms like fungi, amoebae, cellular slime molds, and green algae, are also known to produce cellulose. In fact, green alga Valonia ventricosa is known to produce one of nature's most perfect crystalline forms of cellulose. ${ }^{22}$ Cellulose is also synthesized by marine and freshwater algae, including land plants, such as mosses, ferns, angiosperms, and gymnosperms, ${ }^{22}$ and even by some animals, such as the tunicates. ${ }^{23}$

\section{Structure of cellulose}

Cellulose exists in nature in two states: crystalline and non-crystalline. The crystalline state has further six different polymorphs: cellulose I, II, III $, \mathrm{III}_{\mathrm{II}}, \mathrm{IV}_{\mathrm{I}}$, and $\mathrm{IV}_{\mathrm{II}}$. Cellulose I and II are prevalent and the other polymorphs can be obtained artificially employing chemical or heat treatments. Cellulose I is more abundantly present than cellulose II, and has two allomorphs denominated as I $\alpha$ and I $\beta$. Based on its structure, cellulose can be defined as a linear homopolymer made up of $\beta$-D-glucopyranose units, linked by $\beta$ 1,4-glycosidic bonds with anhydroglucose $\left(\mathrm{C}_{6} \mathrm{H}_{10} \mathrm{O}_{5}\right)$ n, as its monomeric unit (Fig. 1). ${ }^{38}$

The dimeric form of cellulose, cellobiose is a structural repetitive unit of the cellulose chain, which is made up of two glucose residues linked by $\beta-1,4$ linkage. The degree of polymerization of cellulose, $n$, is dictated by the number of monomers present in the cellulose chain and varies between 10,000 to $15,000 .^{22}$ Cellulose is an amphiphilic structure with a clear demarcation of polar $(\mathrm{OH})$ and nonpolar $(\mathrm{CH})$ patches. The $\beta$ $(1,4)$ linkage between glucose residues confers unique structural characteristics to cellulose. Cellulose exists in the form of microfibrils, with approximately 36 glucose chains stabilized by intra- and inter-hydrogen bonding, which impart greater stability to microfibrils. ${ }^{39}$ These microfibrils are further organized into superassemblies, such as cell walls, fibers, and pellicles.

Cellulose fibers present in the natural environment lack pure crystallinity. This deviation is believed to be variable and has resulted in the genesis of a notion called "lateral order distribution" of crystallinity, comprising purely crystalline to purely amorphous cellulose fibers with all intermediary degrees of order. ${ }^{40}$ The cellulose fibers contain various types of indentations, such as kinks or twists, or voids such as surface micropores and capillaries. ${ }^{41}$ In addition to imparting a greater surface area to the cellulose fiber, the structural heterogeneity within the fiber results in partial hydration by water on immersion into aqueous media and also permits the penetration of relatively large molecules like 
cellulolytic enzymes via the micropores and capillaries. ${ }^{42}$

Table 1

Chemical composition of different lignocellulosic biomass

\begin{tabular}{|c|c|c|c|c|c|}
\hline \multicolumn{2}{|c|}{ Lignocellulosic biomass } & $\begin{array}{l}\text { Cellulose } \\
(\%)\end{array}$ & $\begin{array}{l}\text { Hemicellulose } \\
(\%)\end{array}$ & $\begin{array}{c}\text { Lignin } \\
(\%)\end{array}$ & References \\
\hline \multirow{4}{*}{ Hardwood } & Oak & 40.4 & 35.9 & 24.1 & [24] \\
\hline & Eucalyptus & 54.1 & 18.4 & 21.5 & {$[24]$} \\
\hline & Hardwood bark & $22-40$ & $20-38$ & $30-35$ & {$[24]$} \\
\hline & Hardwood stems & $40-45$ & $18-40$ & $18-28$ & {$[25]$} \\
\hline \multirow{4}{*}{ Softwood } & Pine & $42-50$ & $24-27$ & 20 & {$[24]$} \\
\hline & Douglas fir & 44 & 11 & 27 & {$[24]$} \\
\hline & Spruce & 45.5 & 22.9 & 27.9 & {$[24]$} \\
\hline & Softwood stem & $34-50$ & $21-35$ & $28-35$ & [25] \\
\hline \multirow{12}{*}{$\begin{array}{l}\text { Agricultural } \\
\text { waste }\end{array}$} & Wheat straw & $35.0-39.0$ & $23.0-30.0$ & $12.0-16.0$ & [26] \\
\hline & Barley hull & 34.0 & 36.0 & $13.8-19.0$ & {$[24]$} \\
\hline & Rice straw & $29.2-34.7$ & $23.0-25.9$ & $17.0-19.0$ & {$[27,28]$} \\
\hline & Barley straw & $36.0-43.0$ & $24.0-33.0$ & $6.3-9.8$ & [29] \\
\hline & Sugarcane bagasse & $25.0-45.0$ & $28.0-32.0$ & $15.0-25.0$ & {$[30]$} \\
\hline & Sorghum straw & $32.0-35.0$ & $24.0-27.0$ & $15.0-21.0$ & {$[24]$} \\
\hline & Corn cobs & $33.7-41.2$ & $31.9-36.0$ & $6.1-15.9$ & {$[31]$} \\
\hline & Corn shank & 33.8 & 20.1 & 31.1 & {$[32]$} \\
\hline & Corn stover & $37-42$ & $20-28$ & $18-22$ & {$[33]$} \\
\hline & Areca nut shell & 38.4 & 17.2 & 25.1 & {$[32]$} \\
\hline & Areca nut sheath & 17.8 & 10.4 & 20.2 & {$[32]$} \\
\hline & Bamboo & 45.7 & 26.5 & 21.1 & [31] \\
\hline \multirow{4}{*}{ Grasses } & Grasses & $25.0-40.0$ & $25.0-50.0$ & $10.0-30.0$ & {$[24]$} \\
\hline & Switchgrass & $35.0-40.0$ & $25.0-30.0$ & $15.0-20.0$ & [34] \\
\hline & Bermuda grass & 25.0 & 35.7 & $9-18$ & [32] \\
\hline & Miscanthus & 40 & 18 & 23 & {$[35]$} \\
\hline \multirow{3}{*}{ Others } & $\begin{array}{l}\text { Waste papers } \\
\text { from chemical pulps }\end{array}$ & $12-20$ & $50-70$ & $6-10$ & {$[36]$} \\
\hline & Newspaper & $40-55$ & $25-40$ & $18-30$ & {$[36]$} \\
\hline & Manure solid fibres & $8-27$ & $12-22$ & $2-13$ & [37] \\
\hline
\end{tabular}

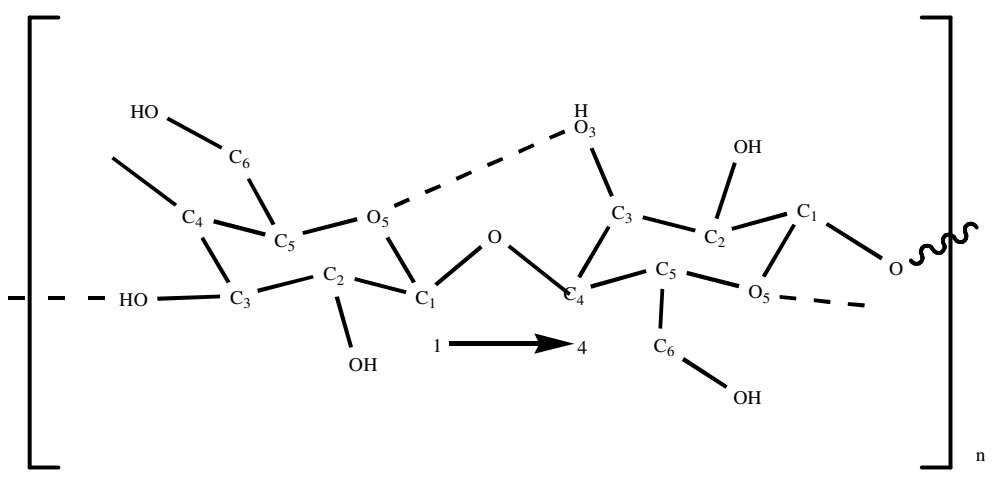

Figure 1: Structure of cellulose

\section{CELLULASE COMPLEXES}

The cellulase is the chief enzyme involved in the breakdown of cellulose into simple sugars. Cellulases act by hydrolyzing the $\beta-1,4$ linkages in the cellulose chains. The families of catalytic modules of cellulases have been classified based on amino acid sequences and crystal structures. ${ }^{43}$ Cellulases also consist of non-catalytic 
carbohydrate-binding modules (CBMs) and modules of known or unknown functions, located at the $\mathrm{N}$ - or $\mathrm{C}$-terminus of a catalytic module.

Cellulolytic microorganisms have evolved different strategies for cellulose degradation, these microorganisms have either discrete uncomplexed cellulases or complexed cellulases. ${ }^{44}$ In general, most aerobic cellulolytic microorganisms degrade cellulose by secreting a set of individual cellulases, each of which contains a CBM adhered to the catalytic module by a flexible linker peptide. ${ }^{4}$ In the case of anaerobic microorganisms, large multi-enzyme complexes (approx. 1 million molecular mass), called cellulosomes, are present. ${ }^{46}$

\section{Three-dimensional cellulase structure}

The function of cellulase enzymes has been unravelled with the help of crystal structures of glycoside hydrolase $(\mathrm{GH})$. It has been elucidated that CBM and a catalytic domain (CD), connected by a non-structured linker peptide are the two domains present in the endo-cellulases and exocellulases. ${ }^{47} \mathrm{CBMs}$ are non-catalytic, functionally independent domains connected to the catalytic domain of many GHs. Based on fold and carbohydrate recognition, 68 families of CBMs have been classified. ${ }^{48}$ The binding of CBM to the cellulose fibers possibly helps to localize the catalytic modules on crystalline cellulosic substrates and target specific carbohydrate structures, as well as aids in the disintegration of lignocelluloses. ${ }^{49}$ As the catalytic domain of cellulase contains the active site, it must be able to bind, orient, and hydrolyze the $\beta-(1,4)$ glycosidic bond. Interestingly, the presence of a tunnel-like structure around the active site seems to be important in the determination of the enzyme's processivity. ${ }^{50}$ One such highly processive enzyme is Cel7A, with an enclosed "tunnel" that accommodates a single cellulose chain threaded through the active site. On the other hand, less processive enzymes, which lack these tunnels around their active sites, allow cellulases to bind and arbitrarily release cellulose chains.

\section{Catalytic mechanisms}

There are two major catalytic mechanisms for glycosidic bond hydrolysis: retaining and inverting. During the retaining mechanism, glycosidic oxygen is initially protonated via the acid/base catalyst, along with the formation of a glycosyl-enzyme intermediate through the nucleophile. The further step involves the subsequent hydrolysis of the intermediate via attack by a water molecule, generating a product with the same stereochemistry as that of the substrate (Fig. 2a). During the inverting mechanism, single-step protonation of the glycosidic oxygen via the acid/base catalyst takes place, along with the nucleophile activated attack of a water molecule, generating a product with the opposite stereochemistry as that of the substrate (Fig. 2b). The type of mechanism, retaining or inverting, is conserved for a given glycoside hydrolase family and is dictated by various factors, such as the architecture of active-site and atomic distance between the acid/base and nucleophilic residues, such as aspartic and/or glutamic acids. ${ }^{51}$

\section{ENZYME SYSTEM FRAMEWORKS IN MICROORGANISMS \\ Free enzyme system}

In nature, complete cellulase hydrolysis is mediated by the collaborative action of three principal enzymes, viz., endoglucanase (EC 3.2.1.4), exoglucanase including cellobiohydrolases (CBHs) (EC 3.2.1.91) and $\beta$ glucosidase (EC 3.2.1.21). ${ }^{52}$ The amorphous (internal) regions of the fibrils are preferentially hydrolyzed by endoglucanases, by randomly cleaving $\beta$-glycosidic bonds; cellobiohydrolases are exoglucanases, which act to release the cellobiose from the termini of cellulose chains, while $\beta$-glucosidases hydrolyze cellobiose and other cellodextrins into glucose units, thus completing the degradation process. The free cellulases are produced by fungi, bacteria, protozoans, plants and animals, and belong to the glycoside hydrolase $(\mathrm{GH})$ families $^{53}$ (Table 2). More than 48,000 CBM sequences have been classified into 71 CBM families based on sequence similarity, and the structures of 271 representative CBMs have been reported until now. ${ }^{54}$ Based on the structure and potential to affect the function of associated catalytic domain, three types of CBMs (types A, B and C) have been identified. ${ }^{55}$ Type A CBMs interact with the planar surfaces of cellulose by aromatic amino acid side chains of Trp, Tyr and Phe. ${ }^{56}$ Type B CBMs interact with amorphous regions of cellulose and hemicelluloses by an open cleft associated with it. ${ }^{57,58}$ Type C CBMs are believed to bind short soluble oligosaccharides. ${ }^{57}$ Due to the variable binding strategies of these CBMs, 
they have great effects on the catalytic rates of the attached enzyme. ${ }^{59}$

\section{Endoglucanase}

Endoglucanase or carboxymethyl cellulases arbitrarily hydrolyze carboxymethyl cellulose (CMC), resulting in a rapid shortening of cellulose and a gradual increase in reducing sugar concentration. Both the reducing and nonreducing ends of the cellulose chains are exposed by the activity of endoglucanases. ${ }^{60}$ Different catalytic modules belonging to families 5-9, 12, $44,45,48,51$ and 74 are produced by archaea, bacteria, fungi, plants and animals. Generally, fungal endoglucanases contain a catalytic module, with or without a CBM, while bacterial endoglucanases may contain multiple catalytic modules, CBMs, and other modules with unknown function. A cleft/grove-shaped active site is the characteristic feature present in the catalytic modules of most endoglucanases. The cleft-like structure aids in binding and cleaving the cellulose chain and consequently generates an array of small and insoluble cellulose fragment. However, some endoglucanases act "processively", based on their ability to hydrolyze crystalline cellulose and generate cellobiose or longer cellodextrins as the major products. ${ }^{61}$

\section{Exoglucanase}

Exoglucanase acts at the non-reducing end of the cellulose chain and degrades it by splitting the cellobiose units. Exoglucanases are known to act on swollen, partially degraded amorphous substrates and cellodextrins, but are incapable of hydrolyzing the soluble derivatives of cellulose like carboxymethyl cellulose and hydroxyethyl cellulose. Cellobiohydrolase $(\mathrm{CBH})$ is the moststudied exoglucanase. Different $\mathrm{CBHs}$ are produced by many bacteria and fungi, with catalytic modules belonging to families 5, 6, 7, 9, 48 and 74 glycoside hydrolases. Aerobic fungal $\mathrm{CBHs}$ are in families 6 and 7 only; aerobic bacterial $\mathrm{CBHs}$ in families 6 and 48; anaerobic fungal $\mathrm{CBHs}$ are in family 48; and anaerobic bacterial CBHs are in family 9 , as well as $48 .{ }^{62}$

\section{$\beta$-D-glucosidase}

$\beta$-Glucosidases (BG's) hydrolyze soluble cellodextrins and cellobiose to glucose. $\beta$ Glucosidases do not contain a carbohydratebinding module (CBM). Their activity of $\mathrm{BG}$ on insoluble cellulose is negligible. Different BGs are produced by various archaea, bacteria, fungi, plants, and animals, with different catalytic modules belonging to families 1,3 and 9 .

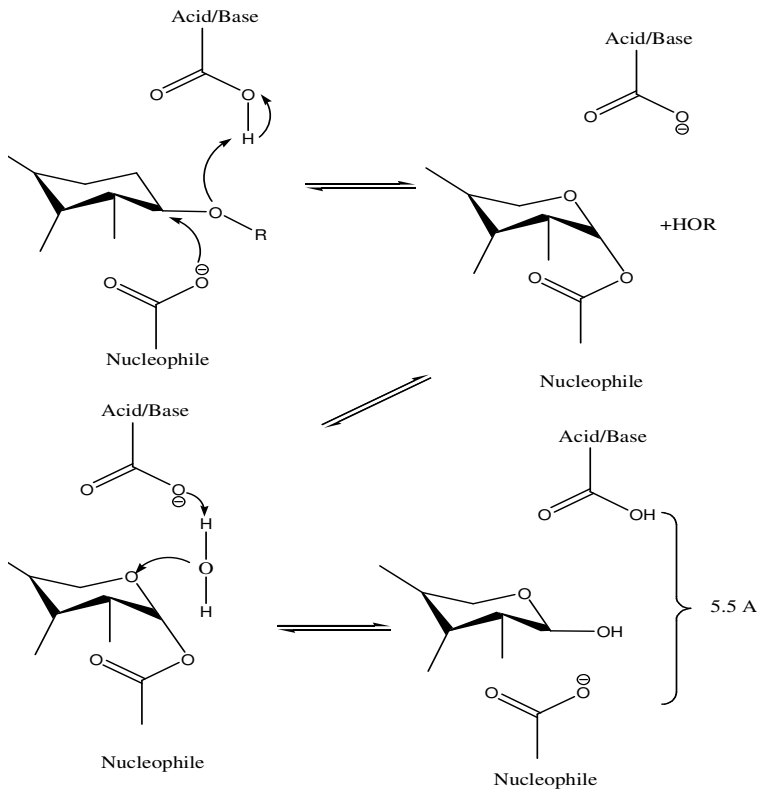

(a)

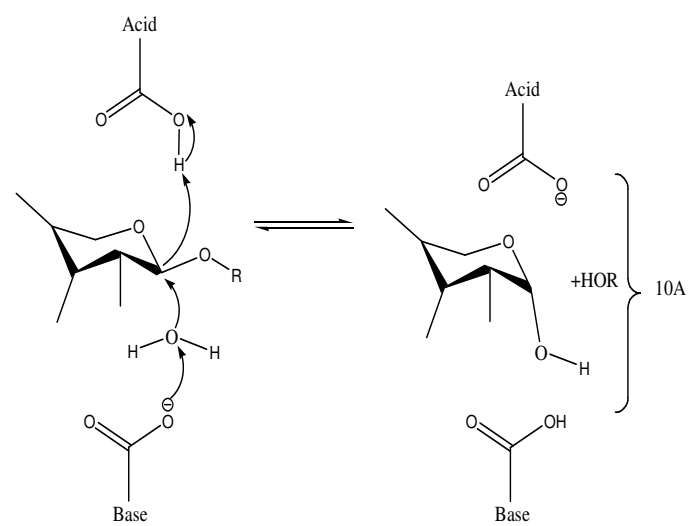

(b)

Figure 2: Major catalytic mechanism of glycosidic bond hydrolysis; a) retaining mechanism, b) inverting mechanism 
Table 2

Glycosidic families exhibiting cellulase activity ${ }^{48}$

\begin{tabular}{|c|c|c|c|}
\hline $\begin{array}{l}\mathrm{GH} \\
\text { family }\end{array}$ & Enzymes & $\begin{array}{c}\text { Catalytic } \\
\text { mechanism }\end{array}$ & $\begin{array}{c}\text { Commercial } \\
\text { enzyme provider }\end{array}$ \\
\hline GH1 & $\begin{array}{l}\beta \text {-Glucosidase, } \\
\beta \text {-galactosidase, } \beta \text {-mannosidase, and } \beta \text {-glucuronidase; } \\
\text { but not } \beta \text {-xylosidase activity }\end{array}$ & Retaining & $\begin{array}{l}\text { Megazyme; } \\
\text { Nzytech; } \\
\text { Prozomix }\end{array}$ \\
\hline GH3 & $\begin{array}{l}\beta \text {-Glucosidase and } \beta \text {-xylosidase activities; glucan } 1,3 \text { - } \\
\beta \text {-glucosidase, glucan } 1,4-\beta \text {-glucosidase and exo- } \\
\text { 1,3(4)-glucanase activities }\end{array}$ & Retaining & $\begin{array}{l}\text { Megazyme; } \\
\text { Prozomix }\end{array}$ \\
\hline GH5 & $\begin{array}{l}\text { Cellulase and hemicellulase activities, including } \\
\text { endoglucanase, xylanase, } 1,3 \text {-mannanase; } \beta \text { - } \\
\text { mannosidase, glucan } 1,3-\beta \text {-glucosidase, } \\
\text { glucan endo- } 1,6-\beta \text {-glucosidase, endo- } 1,6-\beta \text { - } \\
\text { galactanase, and xyloglucan-specific endo- } 1,4-\beta- \\
\text { glucanase activities }\end{array}$ & Retaining & $\begin{array}{l}\text { Megazyme; } \\
\text { Nzytech; } \\
\text { Prozomix }\end{array}$ \\
\hline GH6 & $\begin{array}{l}\text { Cellulase activities in both aerobic bacteria and fungi: } \\
\text { both endo- and exo-glucanase activities }\end{array}$ & Inverting & - \\
\hline GH 7 & $\begin{array}{l}\text { Cellulase activities (fungi): both endo- and exo- } \\
\text { glucanase activities }\end{array}$ & Retaining & \\
\hline GH8 & $\begin{array}{l}\text { Major cellulase family, with members exhibiting } \\
\text { lichenanase and xylanase activities }\end{array}$ & Inverting & $\begin{array}{l}\text { Nzytech; } \\
\text { Prozomix; }\end{array}$ \\
\hline GH9 & $\begin{array}{l}\text { Endo-, processive endo-, and exoglucanase activities } \\
\text { in bacteria, plants and fungi (rare in archaea) }\end{array}$ & Inverting & - \\
\hline GH12 & $\begin{array}{l}\text { Endoglucanase, xyloglucanase, and 1,3(4)- } \beta \text {-glucanase } \\
\text { in the three domains of life (archaea, bacteria and } \\
\text { eukarya) }\end{array}$ & Retaining & Megazyme \\
\hline GH44 & $\begin{array}{l}\text { Endoglucanase and xyloglucanase activities, mainly in } \\
\text { bacteria }\end{array}$ & Retaining & $\begin{array}{l}\text { Nzytech; } \\
\text { Prozomix }\end{array}$ \\
\hline GH45 & $\begin{array}{l}\text { Endoglucanase activity, mainly in fungi (some } \\
\text { bacteria) }\end{array}$ & Inverting & - \\
\hline GH48 & $\begin{array}{l}\text { Cellobiohydrolases acting from the reducing ends of } \\
\text { cellulose and endoprocessive cellulases; mainly in } \\
\text { bacteria }\end{array}$ & Inverting & Nzytech \\
\hline GH74 & Xyloglucanase and endoglucanase activities & Inverting & Nzytech \\
\hline GH124 & Endoglucanase & Inverting & - \\
\hline
\end{tabular}

Based on experimental data or structural homology analysis, it has been established that the stereochemistry of families 1 and 3 BGs is of the retaining type, while that of family $9 \mathrm{BG}$ is of inverting type. Most of the time, aerobic fungi produce extracellular BGs, and anaerobic bacteria restrict the BGs to the cytoplasm. The BGs consist of a pocket-shaped active site, which allows to bind a non-reducing glucose unit and clip off the glucose from cellobiose or cellodextrin. ${ }^{63}$

\section{Self-assembling, aggregated enzyme complex}

Some bacteria, such as Clostridium thermocellum, and a few rumen bacteria, such as Fibrobacter succinogenes and Ruminococcus albus, as well as fungi, have evolved an alternative plant cell wall-degrading enzyme paradigm that involves large, multienzyme complexes commonly bound to the cell surface by long linker peptides and large glycoproteins, called scaffoldins. In contrast to monofunctional enzyme systems, a gigantic, multifunctional mega-Dalton-sized complex, called cellulosome is present in many anaerobic bacteria, produced as a result of non-covalent linkage of a multitude of enzymes to scaffoldin. Cellulosome producing bacterial species are known to be present in diverse ecosystems, including forest and pasture soils, hot spring pools, sewage sludge, compost piles, and the microbiota of both vertebrates and invertebrates. $^{64,65}$ The first cellulosome complex was discovered in the early 1980s, in the highly cellulolytic thermophilic anaerobe Clostridium thermocellum. ${ }^{66}$ Cellulosomes are mainly made up of two building blocks: dockerin containing enzymes or ancillary protein, and cohesin containing structural proteins, called as 
scaffoldins (Fig. 3). The complementary modules - cohesins and dockerins - are tightly bound to each other and their high-affinity, type- and species-specific, non-covalent interaction dictates the integration of enzymes into the complex, as well as its final architecture. ${ }^{67}$ Scaffoldins also contain a dockerin module, which may bind to other scaffoldins and a CBM, which is joined by a short polylinker region to the catalytic domain at the N-terminal. The function of the CBM is to direct the entire cellulosome complex to the target site, i.e. cellulosic biomass. The CBM is composed of approximately 35 amino acids, while the polylinker region is predominantly made up of serine and threonine. ${ }^{68}$ Cellulosomes are either attached to the bacterial cell surface or are released as cell free cellulosomes. ${ }^{69}$ Amongst the bacterial species, mesophiles such as Clostridium cellulolyticum ${ }^{70}$ Clostridium cellulovorans, ${ }^{71}$ Clostridium josuil, Clostridium papyrosolvens, ${ }^{72}$ Ruminococcus albus and Ruminococcus bromii $^{73,74}$ are known to produce simple cellulosome systems, with a single scaffoldin incorporating up to nine enzymatic subunits depending on the number of cohesin modules on the scaffoldin. The cellulosome complex has also been found in anaerobic fungi belonging to the genera Piromyces, Orpinomyces and Neocallimastix, but are markedly different from bacterial cellulosomes as they lack authentic cohesins and bonafide dockerins. ${ }^{75}$ In grampositive bacteria, some enzymes, e.g. a family 5 cellulase from Caldicellulosiruptor ${ }^{76}$ a family 5 endoglucanase from Clostridium josui, ${ }^{77}$ are connected directly to the cell wall by a specialized type of module, the SLH (S-layer homology) module $^{78}$ Though the modular architecture of such enzymes is complicated due to the presence of different modules in a single polypeptide chain, it helps in judicious degradation of insoluble substrates. $^{79}$

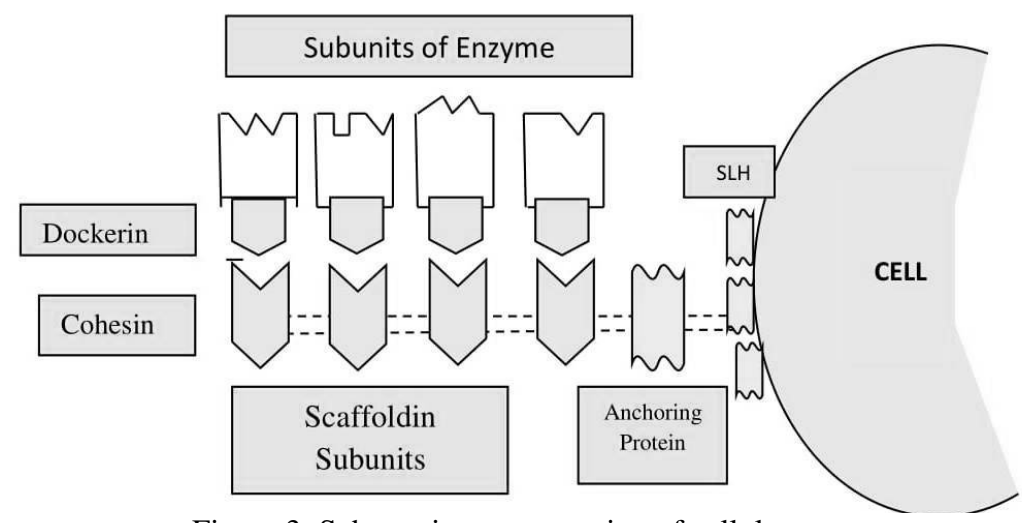

Figure 3: Schematic representation of cellulosome

\section{Designer cellulosomes}

Artificial enzymatic complexes or designer cellulosomes, which are known to efficiently degrade crystalline cellulose, have caught the attention of researchers over the past few decades. There has been a spurt in designer cellulosome related research, as it tends to enhance biomass waste solutions and biofuel production at a worldwide scale. A chimeric scaffoldin containing 6 cohesins is the largest designer cellulosome reported to date. The scaffoldin is regarded with certain technical considerations like limits to the cohesin additions, as a large number of it can result in unstable scaffoldin polypeptide and low expression levels, besides limits to the numbers of available cohesin-dockerin specificities. ${ }^{80}$ Each enzyme in designer cellulosomes interacts specifically with one of the cohesin modules of the chimeric scaffoldin via the dockerin module. A cellulose-specific carbohydrate-binding module of artificial scaffolding helps to translocate the enzyme complex to the desired cellulosic biomass. As an outcome of differential specificity, cohesin modules from different natural cellulosomal species interact with desired matching dockerinbearing enzymes, e.g. type I cohesins will bind type I dockerins of some species, but not others. ${ }^{81}$ Designing cellulosomes can be achieved by assembling the components of native and nonnative cellulosomes, as well as chimeric monofunctional enzymes possessing relevant 
dockerin modules. To achieve the target of generating highly specific cellulolytic complexes, only the desired number of enzymes with specific activity is added in an ordered fashion. ${ }^{82}$ This ordered incorporation of selected enzymes over the random incorporation helps to enhance the scaffoldin flexibility, improves the proximity of the cellulases in the complex and facilitates the specific targeting of CBM on the substrate, eventually improving the synergism between cellulases. ${ }^{83}$ The ability of the adaptor scaffoldin to incorporate a large number of enzymes and attach to an additional scaffoldin has helped in the construction of hexavalent adaptor scaffoldins with three type II cohesins for enzyme integration, a single type II dockerin for interaction with an additional scaffoldin, and a carbohydrate-binding module for specific targeting to cellulosic biomass. ${ }^{84}$ In a recent study by Kahn et al., ${ }^{85}$ a hyper-thermostable cellulosome complex, comprising three pairs of cohesins and dockerins, was reported to exhibit maximum enzymatic activity on microcrystalline cellulose at $75^{\circ} \mathrm{C}$.

\section{Multifunctional enzyme systems}

Multifunctional enzymes are considered to be a prototype, intermediate between monofunctional enzymes and cellulosomes. The multifunctional enzymes have several characteristic features: i) they are products of a single gene, ii) have high molecular weight, iii) have two or more catalytic activities, iv) have one or several CBMs. ${ }^{86}$ In nature, they exist in both monofunctional enzyme systems and cellulosomal systems. Based on substrate specificities, monofunctional enzymes are grouped into four different classes: cellulasecellulase, cellulase-hemicellulase, hemicellulasehemicellulase, and hemicellulase-carbohydrate esterase systems. ${ }^{87}$ A study by Yarbrough et al. ${ }^{88}$ has reported that the multifunctional enzyme complex from Caldicellulosiruptor bescii outperforms the free enzyme system of Trichoderma reeseii in terms of total cellulose conversion, sugar production, and nano-cellulose production.

\section{DIVERSITY OF CELLULOLYTIC MICROORGANISMS}

Cellulolytic microorganisms, which include bacteria, fungi and protozoans, are known to be present in diverse habitats and perform their characteristic activities, e.g. free-living microbes convert the cellulosic biomass to the assimilable form of sugars, are present in the digestive tract of ruminants, in the guts of wood-degrading termites and worms, in soils, swamps, marshes, water bodies and seawater sediments, in rotting grasses, leaves, wood, in cotton bales, sewage sludge, silage and compost heaps, in muds and decaying vegetable matter, in extreme environments, like hot and volcanic acid, and alkaline springs. ${ }^{89}$ They are also known to be present in symbiotic association with secondary microorganisms. ${ }^{90}$

\section{Cellulolytic actinomycetes}

The past few decades have witnessed an increase in the interest for the isolation of cellulolytic actinomycetes. Actinomycetes are known to efficiently degrade lignocellulosic biomass, as they produce a host of extracellular hydrolases, like cellulases, hemicellulases, xylanases, proteases, pectinases and amylases. The cellulase producing actionomycetes have been reported to belong to the following genera: Cellulomonas, Streptomyces, Micromonospora, Actinoplanes, Nocardia, Microbispora, Thermobifida, Saccharopolysopra, Streptoverticillium, Pseudonocardia, Actinopolyspora, Streptosporangium, Intrasporangium and Thermoactinomycetes. ${ }^{44,91-93}$ In most of the actinomycetes, cellulases are secreted extracellularly, using specific secretion pathways, i.e., Sec general secretion system and sec independent twin-arginine translocation (TAT) systems, discovered in Thermobifida ${ }^{94}$

\section{Cellulolytic bacteria}

There has been tremendous interest in the exploration of bacterial species for their cellulolytic activities, as compared to other microorganisms due to several reasons, like high growth rate and ability to inhabit distinctly wide types of habitats that produce cellulolytic enzymes resistant to environmental stresses. ${ }^{95}$ Most of the bacterial species can catalyze the conversion of soluble derivatives or amorphous regions of crystalline cellulose. However, a few cellulolytic bacteria called "true cellulolytic" can bring out the extensive hydrolysis of the crystalline cellulose, whereas those bacterial species that do not produce a complete cellulase system are called "pseudocellulolytic". ${ }^{96}$ The best characterized aerobic cellulolytic bacteria species are Cellulomonas biazotea, Cellvibrio gilvus, Microbispora bispora and Bacillus sp., while anaerobic cellulolytic bacteria are Acetivibrio cellulolyticus, Clostridium thermocellum, 
Ruminococcus albus and Fibrobacter succinogenes. $^{68}$ Several cellulolytic bacterial genera dwelling in the marine environment have also been identified. ${ }^{97}$ Saccharophagus degradans $2-40^{\mathrm{T}}$ is reported to be the first marine bacterium capable of degrading cellulosic algae and higher plant material. ${ }^{98}$ The genomic analysis of $S$. degradans $2-40^{\mathrm{T}}$ revealed that its genome codes 15 have exceptionally long polypeptides in the range of 274 to $1600 \mathrm{kD} .^{99}$

\section{Cellulolytic fungi}

Among all the microorganisms, fungi are considered to be the most versatile cellulolytic microorganisms, contributing to cellulose breakdown to the level of 80 percent on the earth. ${ }^{100}$ The cellulolytic fungi are predominantly the members of ascomycota, basidiomycota, and deuteromycota, as well as some chytrids present in the rumen of some animals. The fungal species are preferred for the production of cellulase, as they secrete highly adaptive, extracellular cellulase in large quantities. ${ }^{101}$ Fungal cellulases can hydrolyze lignocellulosic biomass by secreting a diverse set of hydrolytic and oxidative enzymes. $^{102}$ The white-rot fungus, e.g. Phanerochaete chrysosporium, and soft-rot fungi, e.g. Fusarium solani, Penicillum funiculosum, Talaromyces emersonii, Trichoderma koningii and Trichoderma reesei, are the best characterized cellulolytic fungus. The most accepted commercial microbes with highly cellulolytic potential are Aspergillus fumigatus, Aspergillus nidulans, Aspergillus acculeatus, Aspergillus niger, Aspergillus oryzae, Melanocorpus albomyces, Trichoderma koningii, Trichoderma viride, Penicillium fumiculosum, Talaromyces emersonii, Humicola grisea, H. insolens, Fusarium solani, Irpex lactius, Sclerotium rolfsii etc. ${ }^{101,103}$ The crude enzymes produced by Trichoderma and Aspergillus are widely available commercially, as they are known to be copious producers of cellulase. ${ }^{104-106}$

\section{Cellulolytic gastropod mollusks}

One of the most diverse groups of living organisms, comprising up to 50,000 species, is constituted by Phylum mollusca. The phylum is divided into seven classes, i.e. aplacophora, polyplacophora, monoplacophora, gastropoda, cephalopoda, pelecypoda and scaphopoda, of which gastropods constitute the lagest group (80 percent). ${ }^{107}$ The most dominant species of gastropoda are slugs and snails, e.g. Achatina fulica, Achatina achatina and Archachatina marginata. Their evolutionary successful invasion is attributable to their ability to feed on a great variety of organic matter, including lignocellulosic biomass, not only by the action of their enzymatic reservoir, but also by the activity of characteristic and highly adaptive microbiota that is present in their gut as symbiont. ${ }^{108}$ The gut microbiota consists of bacteria, such as Fibrobacter succinogenes, Ruminococcus flavefaciens and Ruminococcus albus and some fungi, which are responsible for the degradation of plant cell walls constituents like cellulose and hemicelluloses. ${ }^{109,110}$ The metagenomic analysis of the microbiota of giant land snail Achatina fulica revealed the presence of coding sequences for oligosaccharide-degrading enzymes, as well as for novel cellulase and hemicellulase. ${ }^{111}$ Pinheiro et $a .^{112}$ demonstrated the presence of cellulolytic flora belonging to Aeromonas species in the gastrointestinal tract of snail Achatina fulica. Pawar et al. ${ }^{113}$ reported the presence of members of Enterobacteriaceae in the gastrointestinal (GI) tract of Achatina fulica exhibiting potential CMCase and/or avicelase activity.

\section{Cellulolytic insects}

Insects represent a highly variable group of organisms, with about 9 million different kinds of living insects, an estimated biomass of $10^{19}$ approximately. ${ }^{114}$ However, their niche and food source varies widely. Over time, insects have been able to evolve strategies for effective degradation of lignocellulosic biomass as source of energy. ${ }^{115}$ Termites (order: Isoptera), includes seven families: Serritermitidae, Termitidae, Kalotermitidae, Mastotermitidae, Termopsidae, Rhinotermitidae, Hodotermitidae, Serritermitidae, Termitidae, with about 2,300 species belonging to 200 genera. ${ }^{116}$ The gut of termites is a rich source of diverse microorganisms, like bacteria, fungi, and protozoans, which have the potential to efficiently degrade cellulose and hemicelluloses. ${ }^{117}$ The first insect cellulase was discovered in 1998 in termite Reticulitermes speratus, encoding an endo- $\beta(1,4)$ glucanase by the activity of RsEG. ${ }^{118}$ The cellulase producing genes are also known to be found in Hymenoptera (wasps, honeybees), Hemiptera (aphids) and Phthiraptera (lice). ${ }^{119}$ There have been numerous reports on the cellulolytic activity of various insects, such as Reticulitermes flavipes, ${ }^{120}$ Anoplophora glabripennis, ${ }^{121}$ Tenebrio molitor, ${ }^{122}$ Pachnoda 
marginata,${ }^{123}$ Zootermopsis angusticollis, ${ }^{124}$ silver cricket Lepisma sp., ${ }^{125}$ Tipula abdominalis, ${ }^{126}$ Saperda vestita, Dendroctonus frontalis, ${ }^{127}$ and Pachnoda marginata. ${ }^{128}$

\section{Cellulolytic microalgae}

In 2012, it was experimentally established that not only heterotrophic organisms, but also photosynthetic microalga Chlamydomonas reinhardtii can utilize cellulose for growth in Csources limiting conditions by secreting endocellulases. ${ }^{129}$ It has been found that the sequences of catalytic domains (CDs) of algae belong to the inverting GH9 family of CAZymes (carbohydrate-active enzymes). Glucanases (GH family 9) are the most conserved cellulases and are prevalently found in bacteria, fungi, amoebozoa, invertebrate metazoans, mosses, ferns, gymnosperms and angiosperms. ${ }^{130}$ Guerriero et al. ${ }^{131}$ reported that CDs of all algal enzymes have endoglucanase and mixed exo/endo types of activities, along with the presence of novel CBMs and PS-rich linkers, which make them an ideal candidate for cellulosic biomass degradation.

\section{Cellulolytic rumen microorganisms}

The ruminant stomach contains crude fiber, such as cellulose, starch and xylan, not completely converted to animal products. ${ }^{132}$ These materials are fermented by the microbial community, including bacteria, fungi and protozoa. ${ }^{133}$ Rumen microbial ecosystem comprised $10^{10}-10^{11}$ bacterial cells $/ \mathrm{mL}, 10^{4}-10^{6}$ protozoan cells $/ \mathrm{mL}$, and $10^{3}-10^{5}$ anaerobic fungi zoospores $/ \mathrm{mL}$. $^{134}$ The predominant cellulolytic bacteria present in the rumen are Bacillus, Paenibacillus, Pseudomonas, Clostridium, Cellulomonas, Thermomonospora, Ruminococcus, Bacteroides, Erwinia, Acetivibrio, Methanobrevibacter, Gluconacetobacter, Rhodobacter, Fibrobacter, Ruminococcus. ${ }^{135-141}$

\section{Cellulolytic thermophiles}

There has been a manifold increase in the demand for thermostable enzymes lately, which has proved to be a major thrust for the intensive research on such enzymes. There are several advantages of using thermostable enzymes, particularly cellulase, at the industrial scale - for instance, at higher temperatures cellulose swells up, facilitating its easy breakdown and thus significantly improving the overall economy of the process. ${ }^{142,143}$ A large number of bacterial and fungal species have been reported to produce thermostable cellulase.

\section{Thermophilic cellulolytic bacteria}

A large number of bacterial species, both aerobic and anaerobic like Bacillus and Clostridium, have been reported to produce thermostable cellulase enzymes. ${ }^{144}$ A thermostable cellulase with optimal activity at 60 ${ }^{\circ} \mathrm{C}$ has been reported to be produced by Bacillus strains isolated from hot springs, India. ${ }^{145}$ Archaebacteria, like Pyrococcus furiosus and Pyrococcus horikoshii, have been reported to produce thermostable cellulases with optimal activity at $102-105{ }^{\circ} \mathrm{C} .{ }^{146}$ Sulfolobus solfataricus MT4, Sulfolobus acidocaldarius and Sulfolobus shibatae have been shown to produce significant amounts of thermostable $\beta$-glucosidases. ${ }^{147}$ Highly thermostable cellulases acting at $95{ }^{\circ} \mathrm{C}$ have been reported from Thermotoga maritima MSB8. ${ }^{148}$ Thermotoga sp. FjSS3-B1 also produces highly thermostable cellobiase active at $115{ }^{\circ} \mathrm{C} .{ }^{149}$ Endocellulase with maximal activity at 85-95 ${ }^{\circ} \mathrm{C}$ was isolated from the thermophile Anaerocellum thermophilum. ${ }^{150}$ A thermophilic strain Stenotrophomonas maltophilia isolated from Nambor reserve forest reported maximum cellulase activity of $0.43 \mathrm{IU} / \mathrm{mL} .^{151}$ A thermophilic cellulase-producing bacterium isolated from a hot spring showed maximum activity at $60{ }^{\circ} \mathrm{C} .{ }^{152}$

\section{Thermophilic cellulolytic fungi}

Thermophilic fungi grow at a maximum temperature of $50{ }^{\circ} \mathrm{C}$ or above, and a minimum of $20{ }^{\circ} \mathrm{C}$ or above.$^{63}$ The best source of cellulases is Trichoderma sp., however, the major bottleneck with Trichoderma cellulases is that it produces very low $\beta$-glucosidase activity and the enzyme is subject to product inhibition. Kalogeris et al. ${ }^{153}$ reported that thermophilic fungus Thermoascus aurantiacus under optimal growth conditions resulted in $1572 \mathrm{U}$ of endoglucanase and $101.6 \mathrm{U}$ of $\beta$-glucosidase per $\mathrm{g}$ of carbon source. Myceliophthora thermophila JCP 1-4 on solidstate fermentation using lignocellulosic materials as substrates produced endoglucanase $(357.51 \mathrm{Ug} / \mathrm{L}), \quad \beta$-glucosidase $\quad(45.42 \mathrm{Ug} / \mathrm{L})$, xylanase $(931.11 \mathrm{Ug} / \mathrm{L})$ and avicelase $(3.58 \mathrm{Ug} / \mathrm{L})$, found to be active at $55-70{ }^{\circ} \mathrm{C}$ and stable at $30-60{ }^{\circ} \mathrm{C} .{ }^{154}$ Reddy et al. ${ }^{155}$ isolated thermophilic robust cellulolytic fungal strains identified as A. niger, A. flavus, Nigrospora sphaerica, Chaetomium globosum, Cladosporium 
cladosporides, Trichoderma sp. and Penicillium from different soil samples. Chaetomium thermophilum, Sporotrichum thermophile, $T$. emersonii and Thermoascus aurantiacus grew well and decomposed cellulose very rapidly by producing thermostable cellulases. ${ }^{156}$ Table 3 presents an overview of microbial cellulases and their cellulase activity.

Table 3

An overview of microbial cellulases and their cellulase activity

\begin{tabular}{|c|c|c|c|}
\hline Microorganism & Enzyme activity & $\begin{array}{l}\text { Fermentation } \\
\text { type }\end{array}$ & Reference \\
\hline \multicolumn{4}{|l|}{ Fungi } \\
\hline T. harzianum MTCC 8230 & $\begin{array}{c}\text { Exoglucanase, endoglucanase and } \\
\text { cellobiase activities of } 0.127 \mathrm{IU} / \mathrm{mL}, 0.15 \\
\mathrm{IU} / \mathrm{mL} \text { and } 1.65 \mathrm{IU} / \mathrm{mL} \text {, respectively }\end{array}$ & $\mathrm{SmF}$ & [157] \\
\hline T. reesei $\mathrm{ZU}-02$ & $5.48 \mathrm{IU} / \mathrm{mL}$ (FPase) & $\mathrm{SmF}$ & {$[158]$} \\
\hline A. fumigatus Z5 & 4.94 IU/mL ( $\beta$-glucosidase) & $\mathrm{SmF}$ & [159] \\
\hline A. flavus BS1 & $5408.5 \mathrm{IU} / \mathrm{g}$ (FPase) & SSF & [156] \\
\hline \multicolumn{4}{|l|}{ Bacteria } \\
\hline Paenibacillus terrae & $2.08 \mathrm{IU} / \mathrm{mL}$ (CMCase) & $\mathrm{SmF}$ & [160] \\
\hline $\begin{array}{l}\text { Pseudomonas fulorescens } E . \\
\text { coli, Bacillus subtilis, and } \\
\text { Serratia marscens }\end{array}$ & $\begin{array}{c}0.48 \mathrm{IU} / \mathrm{mL}, 0.56 \mathrm{IU} / \mathrm{mL}, 0.54 \mathrm{IU} / \mathrm{mL} \text { and } \\
0.58 \mathrm{IU} / \mathrm{mL} \text { (CMCase) }\end{array}$ & $\mathrm{SmF}$ & {$[161]$} \\
\hline Cellulomonas sp.YJ5 & 60 IU/mL (CMCase) & $\mathrm{SmF}$ & [162] \\
\hline Bacillus sp. & 68 IU/mL (CMCase) & $\mathrm{SmF}$ & {$[163]$} \\
\hline Bacillus sp. & 246 IU/mg protein (CMCase) & $\mathrm{SmF}$ & [164] \\
\hline Paenibacillus sp. & $2655 \mathrm{IU} / \mathrm{mg}$ protein (CMCase) & $\mathrm{SmF}$ & [165] \\
\hline \multicolumn{4}{|l|}{ Thermophilic Bacteria } \\
\hline Caldibacillus cellulovorans & 32 IU/mL (CMCase) & $\mathrm{SmF}$ & [166] \\
\hline Bacillus licheniformis C55 & $0.13 \mathrm{IU} / \mathrm{mL}$ (CMCase) & $\mathrm{SmF}$ & [167] \\
\hline Caldicellulosiruptor owensensis & $532.4 \mathrm{mU} / \mathrm{mg}(\beta$-D-glucosidase $)$ & $\mathrm{SmF}$ & [168] \\
\hline Bacillus vallismortis $R G-07$ & $4105 \mathrm{IU} / \mathrm{mL}$ (CMCase) & $\mathrm{SmF}$ & [169] \\
\hline \multicolumn{4}{|l|}{ Thermophilic fungi } \\
\hline $\begin{array}{l}\text { Myceliophthora thermophila } \\
\text { JCP } 1-4\end{array}$ & $\begin{array}{c}\text { Endoglucanase }(357.51 \mathrm{IU} / \mathrm{g}), \beta- \\
\text { glucosidase }(45.42 \mathrm{IU} / \mathrm{g}), \text { xylanase }(931.11 \\
\mathrm{IU} / \mathrm{g}) \text { and avicelase }(3.58 \mathrm{IU} / \mathrm{g})\end{array}$ & SSF & [170] \\
\hline $\begin{array}{l}\text { Aspergillus fumigatus M.7.1 and } \\
\text { Myceliophthora thermophila } \\
\text { M.7.7 }\end{array}$ & $\begin{array}{c}\text { Xylanase (7238 IU/g) and } \beta \text {-glucosidase } \\
(40.4 \mathrm{IU} / \mathrm{g}) \text { by } A . \text { fumigatus } \mathrm{M} .7 .1 ; 1044.6 \\
\mathrm{IU} / \mathrm{g} \text { of xylanase and } 54 \mathrm{IU} / \mathrm{g} \text { of CMCase } \\
\text { by } M . \text { thermophila M.7.7 }\end{array}$ & SSF & [171] \\
\hline $\begin{array}{l}\text { Aspergillus fumigatus JCM } \\
10253\end{array}$ & $\begin{array}{c}\text { CMCase }(26.2 \mathrm{IU} / \mathrm{mL}), \text { FPase }(18.2 \\
\mathrm{IU} / \mathrm{mL}), \beta \text {-glucosidase }(0.87 \mathrm{IU} / \mathrm{mL}) \text {, and } \\
\text { xylanase }(2.6 \mathrm{IU} / \mathrm{mL})\end{array}$ & SSF & [172] \\
\hline Thielavia sp. & $20 \mathrm{IU} / \mathrm{ml}$ (CMCase) & SSF & [173] \\
\hline \multicolumn{4}{|l|}{ Actinomycetes } \\
\hline $\begin{array}{l}\text { Streptomyces argenteolus } \\
\text { AE58P }\end{array}$ & $0.42 \mathrm{IU} / \mathrm{mL}$ (CMCase) & $\mathrm{SmF}$ & [174] \\
\hline Streptomyces ruber & 25.6 U/mL (CMCase) & $\mathrm{SmF}$ & [175] \\
\hline Streptomyces sp. & $\begin{array}{c}0.26 \mathrm{IU} / \mathrm{mL} \text { (CMCase);18.54 IU/mL } \\
\text { (Xylanase) }\end{array}$ & $\mathrm{SmF}$ & [176] \\
\hline Streptomyces G12 strain & $0.1 \mathrm{IU} / \mathrm{mL}$ (CMCase) & $\mathrm{SmF}$ & [177] \\
\hline Streptomyces longispororuber & 25.08 IU/mL (CMCase) & $\mathrm{SmF}$ & [178] \\
\hline
\end{tabular}

\section{CONVERSION OF RICE STRAW INTO BIOETHANOL}

The depletion of fossil fuel, global warming, and the reduction of natural resources have directed the research attention to bioethanol production from lignocellulosic biomass as an alternative energy source. ${ }^{179}$ Although, extensive research has been carried out on ethanol production from rice straw, ${ }^{180}$ the manufacturing process of the ethanol has not been realized yet, because of the high costs involved in collection and preservation from rice field ridge, high cost of 
cellulase, fermentation system, etc. Therefore, the development of effective and cost-efficient ethanol production systems from rice straw is the need of the hour to achieve the aim of novel energy supply. ${ }^{181}$

\section{Bioethanol: an eco-friendly fuel}

Bioethanol is one of the largest sources of renewable and sustainable energy due to its unique economic and environmental benefits. Bioethanol holds high prospects for mitigating the problem of greenhouse gas emission as it represents a closed carbon dioxide cycle (Fig. 4). It also plays an important role at the community level by boosting the income of smallholder farmers, as farmers can cultivate energy crops that yield an income, while meeting their food needs at the same time. ${ }^{182}$ The bioethanol contains $35 \%$ oxygen, complete combustion of which results in exhaust emissions with less toxicity as compared to conventional fuels. ${ }^{183}$ It has been estimated that gasoline blending with ethanol has reduced $\mathrm{CO}_{2}-$ equivalent greenhouse gas emissions from the

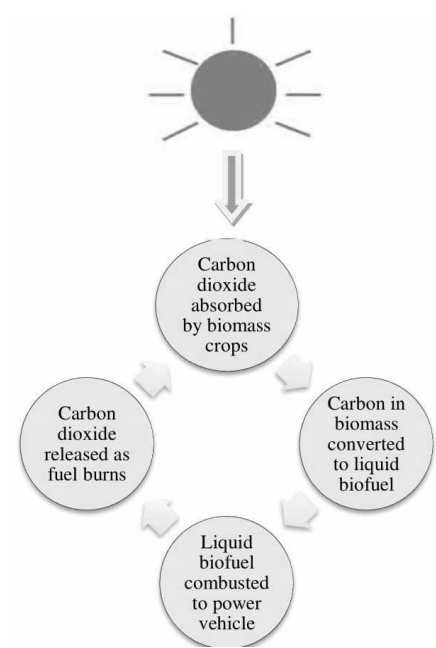

Figure 4: Biofuel carbon cycle transportation sector by 55.1 million metric tons in 2018. ${ }^{184}$ Although bioethanol is currently produced worldwide, the United States is the world's leader in bioethanol production (Fig. 5). ${ }^{185}$

\section{Generations of bioethanol}

There are various generations of bioethanol categorized as first through fourth (Fig. 6). Firstgeneration biofuels are produced from starch or sugar-based feedstocks. ${ }^{186}$ However, firstgeneration biofuels are replete with serious setbacks, as they pose a stiff competition to food production. ${ }^{187}$ Thus, the focus has been shifted to second-generation biofuels that are produced from lignocellulosic feedstock. The lignocellulosic biomass consists of forest, agricultural and municipal wastes, including non-food and dedicated energy crops. ${ }^{188,189}$ The third generation of biofuels is based on microalgae or unicellular microorganisms derived from eukaryotes and prokaryotes, including cyanobacteria, such as Chlorella, Nanochloropsis or Botryococcus. ${ }^{190}$

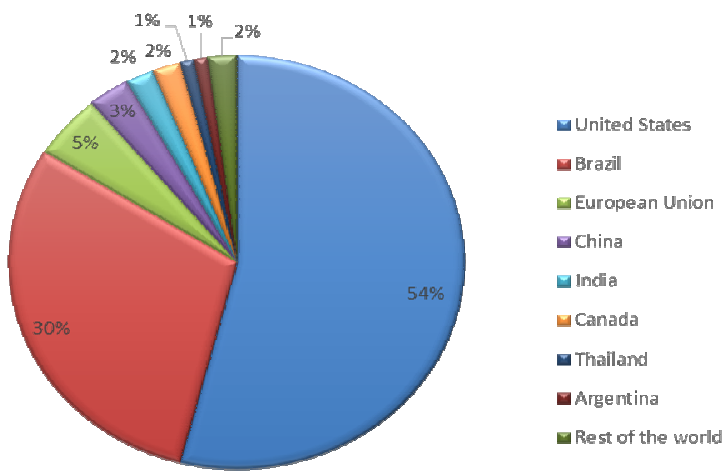

Figure 5: Global fuel ethanol production in 2019 by country $^{185}$

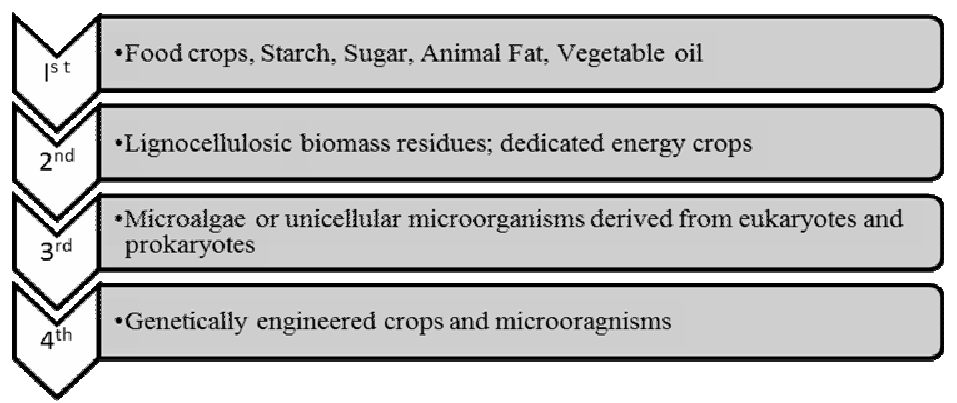

Figure 6: Schematic representation of different generations of bioethanol 


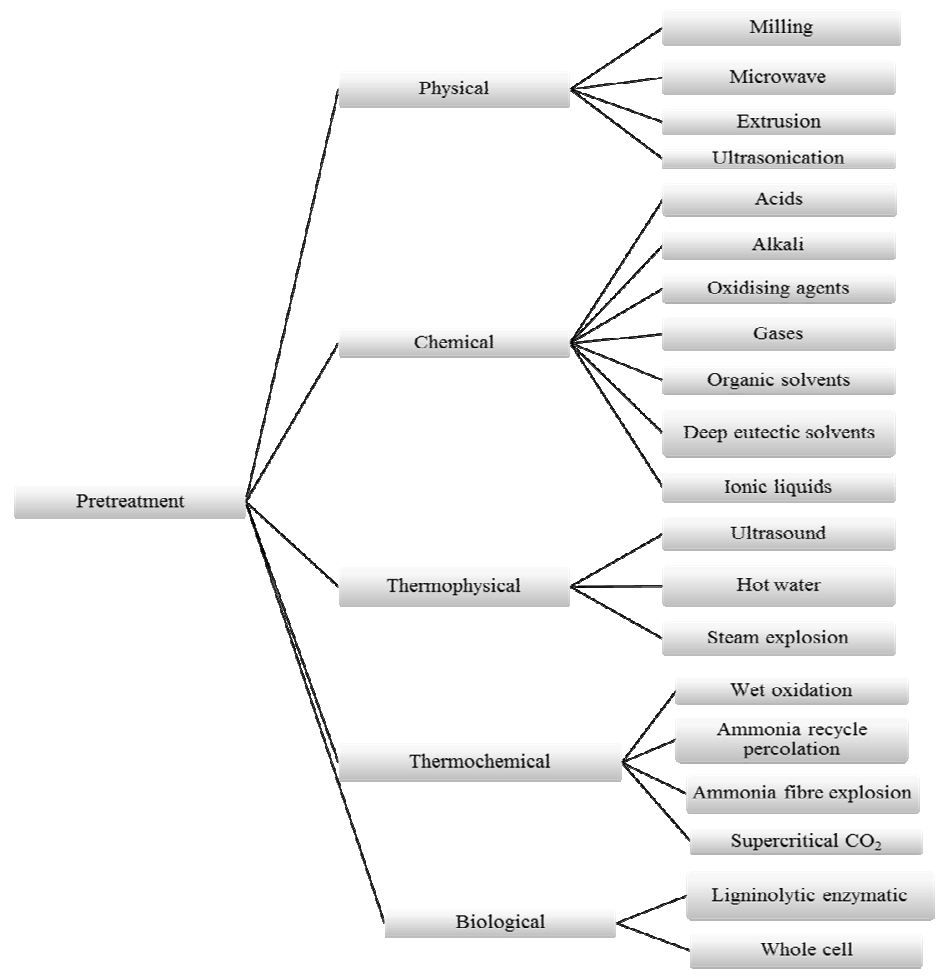

Figure 7: Pretreatment methods of rice straw

Fourth-generation biofuels are also called photobiological solar fuels and electrofuels. Photobiological solar fuels are based on direct conversion of solar energy into fuel, using inexhaustible, cheap, and widely available raw materials. The revolutionary development of photobiological solar fuels depends on the synthetic biology of algae and cyanobacteria, and requires the discovery of new-to-nature solutions, construction of the synthetic living factories, and designer microorganisms. Likewise, electrobiofuels are based on the combination of photovoltaics or inorganic water-splitting catalysts with metabolically engineered microbial fuel production pathways. ${ }^{191}$

\section{Rice straw: an ideal feedstock for cellulase and bioethanol production}

Rice straw has been widely acclaimed as the most attractive feedstock for bioethanol production. According to the Food and Agriculture Organization (FAO), approximately 1140 million tons of rice straw is generated globally. ${ }^{192}$ About half of this waste is burnt in the fields, resulting in massive amounts of obnoxious gases, such as carbon monoxide, nitrous oxides, volatile organic compounds, and, suspended particulate matter. ${ }^{193}$ Thus, the problem to this solution lies in the conversion of surplus rice straw into value-added products like bioethanol. Rice straw predominantly comprises cellulose (32-47\%), hemicelluloses (19-27\%) and lignin (5$24 \%$ ), with $18.8 \%$ ashes. ${ }^{194}$ However, to disrupt the recalcitrant structure of rice straw, in which hard and crystalline cellulose is entangled with lignin and hemicelluloses, physical and/or chemical pretreatment or a combination of these processes is required as a prerequisite step (Fig. 7). The physical treatment includes steaming ${ }^{195}$ steam explosion, ${ }^{196}$ grinding and milling, ${ }^{197}$ and irradiation. ${ }^{198}$ The chemical treatment includes alkali, ${ }^{198}$ acids, ${ }^{199}$ and ammonia treatment. ${ }^{200}$ The biological pretreatment has been carried out using white-rot fungi, e.g. Phanerochaete chrysosporium, Ceriporiopsis subvermispora and Pleurotus ostreatus, which can metabolize lignin by secreting a set of ligninolytic enzymes like manganese peroxidase, lignin peroxidase, and laccase. ${ }^{201}$ Likewise, several actinomycetes produce enzymes involved in lignocellulose degradation. The combined processes involve two-step pretreatment with dilute sulfuric acid and aqueous ammonia, ${ }^{202}$ microwave with acid and alkali, ${ }^{203}$ ultrasonic radiation and ionic liquids. ${ }^{204}$ 
Apart from utilizing rice straw as a feedstock for bioethanol production, it can also serve as a promising substrate for cellulase production. The rice straw as a substrate not only provides solid support for fungal growth, but also acts as a viable source of carbon and nutrients. ${ }^{205}$ As reported by Singla et al., ${ }^{206}$ the addition of soybean pod husk to paddy straw in equal proportions resulted in significantly higher filter paper, CMCase, cellobiase, and xylanase activities, of $89.54 \mathrm{nmol} / \mathrm{min} / \mathrm{gds}, \quad 405.37$ $\mathrm{nmol} / \mathrm{min} / \mathrm{gds}, 171.26 \mathrm{nmol} / \mathrm{min} / \mathrm{gds}$ and 3765.76 $\mathrm{nmol} / \mathrm{min} / \mathrm{gds}, 72$ hours after incubation by Aspergillus fumigatus CST2. Kogo et al. ${ }^{207}$ evaluated rice straw as a carbon source for Trichoderma reesei and Humicola insolens, to produce enzymes for rice straw hydrolysis. The authors reported that the enzyme activity of $T$. reesei cultivated in medium containing $\mathrm{NH}_{4} \mathrm{OH}$ treated rice straw was 4-fold higher than enzyme from cultures grown in Avicel (form of refined cellulose) medium. Rice straw pre-treated with sodium hypochlorite $(\mathrm{NaClO})$ resulted in the highest FPase activity of $24.14 \mathrm{U}$ by Phanerochaete chrysosporium on the $5^{\text {th }}$ day of incubation. ${ }^{208}$ In contract to the above findings, untreated rice straw showed higher activity of FPase, CMCase, $\beta$-glucosidase and xylanase with values of $6.25 \mathrm{~g} / \mathrm{substrate}, 111.31 \mathrm{~g} / \mathrm{substrate}$, $173.31 \mathrm{~g} /$ substrate and $433.75 \mathrm{~g} / \mathrm{substrate}$, respectively, as compared to $1.72 \mathrm{~g} /$ substrate, $23.01 \mathrm{~g} /$ substrate, $2.18 \mathrm{~g} /$ substrate and 45.46 $\mathrm{g} /$ substrate for FPase, CMCase, $\beta$-glucosidase and xylanase, respectively, for $0.5 \%(\mathrm{w} / \mathrm{v}) \mathrm{NaOH}$ pretreated rice straw. The authors opined the lower activity in pre-treated rice straw is due to the decline in absolute crystallinity of cellulose owing to alkali pretreatment, which is otherwise required for the induction of cellulase enzyme..$^{209}$

\section{Role of cellulase in the conversion of rice straw to bioethanol}

Post pretreatment, hydrolysis of biomass results in the conversion of cellulose and hemicelluloses into simple sugars. The cellulose contains glucans, whereas hemicelluloses contain polymers of several sugars, such as xylan, galactan, mannan and arabinan. Consequently, glucose is the predominant product of cellulose hydrolysis, whereas the hemicelluloses yield pentoses and hexoses. ${ }^{210}$ The hydrolysis process can be accomplished in two ways; enzymatically by (hemi) cellulolytic enzymes or chemically by sulphuric or other acids. ${ }^{211}$ However, enzymatic hydrolysis is a preferred mode as it offers several advantages such as the generation of compounds with lower toxicity, hyper-production of desired product, low input of chemicals and energy, and subtle environmental conditions. ${ }^{212}$ Table 4 presents the enzymatic hydrolysis of various feedstock using indigenous cellulases. The overall schematic of bioethanol production from rice straw is presented in Figure 8.

\section{CHALLENGES IN CELLULOSIC ETHANOL PRODUCTION AND FUTURE RESEARCH}

The cellulosic ethanol production faces several technical and economic hindrances, such as the need for year-round availability of feedstock, efficient and economical pretreatment and saccharification technology, as well as potent ethanologenic strains. ${ }^{222}$ The cost of cellulase production and the development of more efficient, specific and stable cellulases are the real objectives of future research on cellulases. Though a large number of culturable, cellulolytic microorganisms have been isolated from diverse sources, such as compost piles, decomposed organic matter, faeces of ruminants, and hot springs, many habitats, such as synthetic extreme environments, e.g. carwash effluent tanks and drains, which could be potential sources of cellulolytic microorganisms, remain unexplored. Besides, non-culturable microbes are also an excellent source of cellulolytic genes. The most widely recognized approach to exploit these microbes is to construct a metagenomic library, followed by its functional screening. ${ }^{223}$ The cost of cellulase, which greatly contributes to the overall process cost, can be cut short by recycling or immobilization of cellulases. Previous studies point to immobilization of cellulase on nonporous and porous silica, with a retention of $>50 \%$ activity for at least four rounds of recycling, ${ }^{224}$ and to recycling of endocellulases immobilized on activated carbon, zeolite, ion exchange resin, and polystyrene in two different shapes (drop or sheet) and mixtures thereof. The enhancement of cellulase production is another strategy being attempted consistently for reducing the cost of cellulases. 
Table 4

Recent studies on hydrolysis of rice straw using indigenous cellulases

\begin{tabular}{|c|c|c|c|c|c|}
\hline Pretreatment & Cellulase source & Enzyme dose & Process conditions & Outcome & $\begin{array}{l}\text { Referenc } \\
\mathrm{e}\end{array}$ \\
\hline $2 \%(\mathrm{w} / \mathrm{v}) \mathrm{NaOH}$ & $\begin{array}{l}\text { T. harzianum } \\
\text { SNRS3 }\end{array}$ & $\begin{array}{c}\text { FPase, } 6.25 \mathrm{IU} / \mathrm{gs} ; \text { CMCase } \\
111.31 \mathrm{IU} / \mathrm{gs} \text { and } \beta- \\
\text { glucosidase } 173.71 \mathrm{IU} / \mathrm{gs}\end{array}$ & $\begin{array}{c}\text { Substrate conc. 5\% (w/v); incubation temp. } \\
50{ }^{\circ} \mathrm{C} \text { and agitation } 150 \mathrm{rpm} \text {; incubation period } \\
96 \mathrm{~h}\end{array}$ & $\begin{array}{l}29.87 \mathrm{~g} / \mathrm{L} \text { reducing } \\
\text { sugars }\end{array}$ & [213] \\
\hline $2 \%(\mathrm{w} / \mathrm{v}) \mathrm{NaOH}$ & $\begin{array}{l}\text { Aspergillus } \\
\quad \mathrm{CP} 1\end{array}$ & $\begin{array}{l}\text { FPase, } 0.62 \mathrm{IU} / \mathrm{mL}, \mathrm{CMCase} \\
5.9 \mathrm{IU} / \mathrm{mL} \text { and } \beta \text {-glucosidase } \\
1.11 \mathrm{IU} / \mathrm{mL}\end{array}$ & $\begin{array}{c}\text { Substrate conc. } 12 \%(\mathrm{w} / \mathrm{v}) \text {; incubation temp. } \\
55^{\circ} \mathrm{C} \text { and agitation } 150 \mathrm{rpm} \text {; incubation period } \\
36 \mathrm{~h}\end{array}$ & $159.1 \mathrm{~g} / \mathrm{L}$ sugars & [214] \\
\hline Untreated & Aspergillus niger & $10 \mathrm{FPU} / \mathrm{g}$ substrate & $\begin{array}{l}\text { Substrate conc. } 12 \%(\mathrm{w} / \mathrm{v}) \text {; agitation } 150 \mathrm{rpm} \text {, } \\
\text { incubation temp. } 45^{\circ} \mathrm{C} \text {, incubation period } 96 \mathrm{~h}\end{array}$ & $\begin{array}{l}3.62 \mathrm{~g} / \mathrm{L} \text { fermentable } \\
\text { sugars }\end{array}$ & [215] \\
\hline $2 \% \mathrm{NaOH}$ & $\begin{array}{l}\text { Trichoderma } \\
\text { reesei ZM4-F3 }\end{array}$ & $\begin{array}{l}10^{6} \text { spores } / \mathrm{mL} \text { at the rate of } \\
2 \%(\mathrm{v} / \mathrm{v})\end{array}$ & $\begin{array}{c}\text { Substrate conc. } 3 \%(\mathrm{w} / \mathrm{v}) ; \text { temp. } 35^{\circ} \mathrm{C}, \\
\text { agitation } 180 \mathrm{rpm}\end{array}$ & $\begin{array}{l}2.23 \mathrm{~g} / \mathrm{L} \text { reducing } \\
\text { sugars }\end{array}$ & [216] \\
\hline $1 \%$ Sodium hydroxide & $\begin{array}{l}\text { Trichoderma } \\
\text { reesei } \mathrm{F}-418\end{array}$ & $1.2 \mathrm{FPU} / \mathrm{mL}$ & $\begin{array}{c}\text { Substrate conc. } 5 \%(\mathrm{w} / \mathrm{v}) \\
\text { incubation period } 16 \mathrm{~h} \text {, agitation } 100 \mathrm{rpm}\end{array}$ & $1.07 \%$ glucose & {$[102]$} \\
\hline $\begin{array}{l}\text { Steam treatment by } \\
\text { autoclaving }\end{array}$ & $\begin{array}{l}\text { Aspergillus terreus } \\
\text { F98 }\end{array}$ & $\begin{array}{l}2.0 \mathrm{~mL} \text { spore suspension } \\
\quad\left(\text { Spore count } \approx 10^{6}\right. \\
\text { spores } / \mathrm{mL})\end{array}$ & $\begin{array}{c}\text { Saccharification under SSF conditions, } \\
\text { Incubation temp. } 30^{\circ} \mathrm{C} \text {, incubation period } \\
7 \text { days }\end{array}$ & $\begin{array}{l}17.0 \mathrm{~g} / \mathrm{L} \text { total reducing } \\
\text { sugar, } 44.0 \% \\
\text { saccharification }\end{array}$ & [217] \\
\hline $\begin{array}{l}\text { Phenarocheate } \\
\text { chrysosporium } \\
\text { NCIM } 1197\end{array}$ & Aspergillus niger & $1 \times 10^{5}$ condia/mL & $\begin{array}{l}\text { Substrate conc. } 5 \%(\mathrm{w} / \mathrm{v}) \text {, agitation } 180 \mathrm{rpm} \text {, } \\
\text { incubation temp. } 28^{\circ} \mathrm{C} \text {, incubation period } 24 \mathrm{~h}\end{array}$ & $\begin{array}{l}480 \mathrm{mg} / \mathrm{g} \text { reducing } \\
\text { sugars }\end{array}$ & [218] \\
\hline $\begin{array}{l}0.5 \mathrm{M} \mathrm{NaOH} \text { at } 121^{\circ} \mathrm{C} \\
\text { for } 1 \text { hour at the ratio of } \\
1: 10(\mathrm{w} / \mathrm{v})\end{array}$ & $\begin{array}{l}\text { Aspergillus } \\
\text { fumigatus } \\
\text { NITDGPKA3 }\end{array}$ & $40 \mathrm{IU} / \mathrm{g}$ CMCase & $\begin{array}{c}\text { Substrate conc. } 2 \%(\mathrm{w} / \mathrm{v}) \text {, incubation temp. } \\
50{ }^{\circ} \mathrm{C} \text {, agitation } 120 \mathrm{rpm} \text {, incubation period } 36 \mathrm{~h}\end{array}$ & $\begin{array}{c}0.522 \text { g reducing } \\
\text { sugar/g dry substrate }\end{array}$ & [219] \\
\hline $\begin{array}{l}0.5 \mathrm{M} \mathrm{KOH} \text { for } 4 \mathrm{~h} \\
\text { followed by } 0.1 \mathrm{~N} \mathrm{H}_{2} \mathrm{SO}_{4} \\
\text { for } 1 \mathrm{~h} \text { (bath ratio } 1: 10), \\
\text { at room temp. }\end{array}$ & $\begin{array}{l}\text { Aspergillus niger } \\
\text { BK01 }\end{array}$ & $\begin{array}{l}2 \%(\mathrm{v} / \mathrm{v})(12.0 \mathrm{U} / \mathrm{gds} \\
\text { CMCase })\end{array}$ & $\begin{array}{l}\text { Substrate conc. } 10 \%(\mathrm{w} / \mathrm{v}) \text {, incubation temp. } \\
\qquad 40^{\circ} \mathrm{C} \text {, incubation period } 2.5 \mathrm{~h}\end{array}$ & $\begin{array}{l}23.78 \% \text { sugars; } \\
35.96 \% \\
\text { saccharification }\end{array}$ & [220] \\
\hline $\begin{array}{l}\text { Milled and } \\
\text { sieved }(100 \mu \mathrm{m})\end{array}$ & $\begin{array}{c}\text { Bacillus } \\
\text { carboniphilus } \\
\text { CAS } 3\end{array}$ & $250 \mathrm{U} / \mathrm{mL}$ CMCase & $\begin{array}{l}\text { Substrate conc. } 2 \%(\mathrm{w} / \mathrm{v}) \text { incubation temp. } \\
50{ }^{\circ} \mathrm{C} \text {; agitation } 100 \mathrm{rpm} \text {, incubation period } 96 \mathrm{~h}\end{array}$ & $\begin{array}{l}15.56 \mathrm{~g} / \mathrm{L} \text { of reducing } \\
\text { sugars }\end{array}$ & {$[221]$} \\
\hline
\end{tabular}




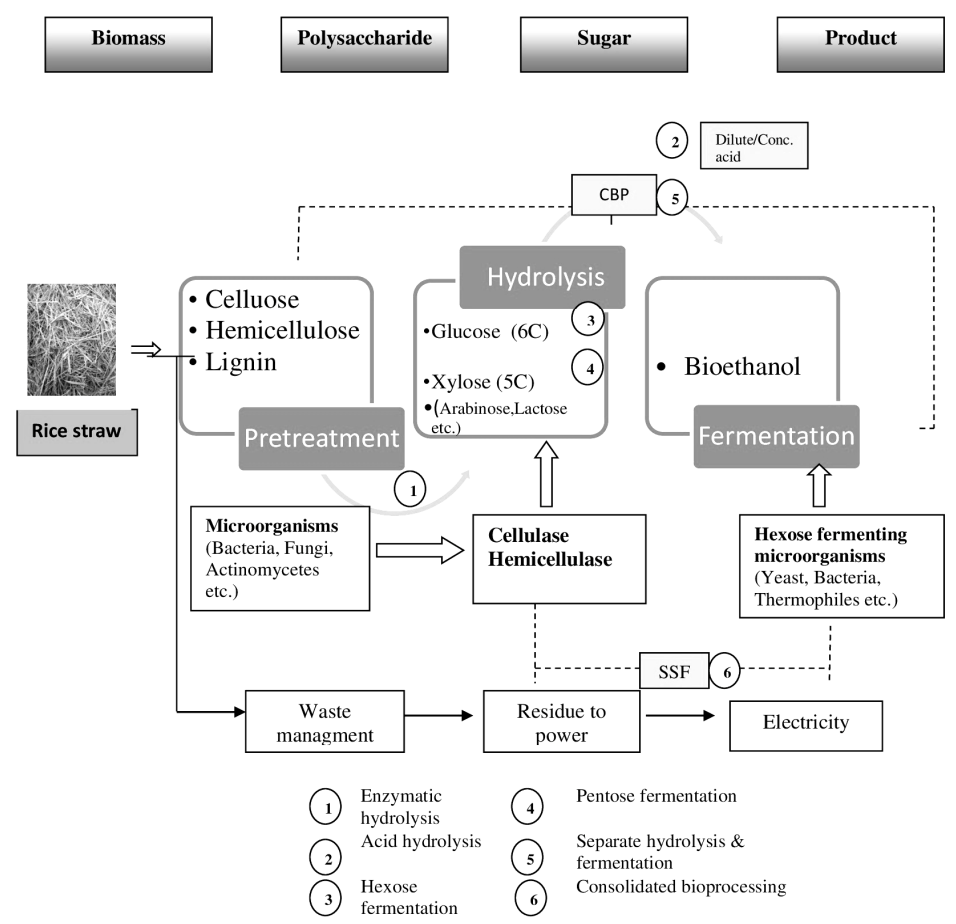

Figure 8: Overall schematic of bioethanol production from rice straw

The use of lignocellulosic biomass for enzyme production, ${ }^{225}$ co-culture or consortium-mediated cellulase production, ${ }^{222}$ the development of recombinant strains by genetic engineering, ${ }^{226}$ protein engineering for remodeling the cellulolytic systems in the microbes, ${ }^{227}$ random mutagenesis by chemical or physical mutagens, ${ }^{228}$ innovative bioreactor geometries and process strategies, e.g. biomass conversion at high-solids loads, submerged fermentation $(\mathrm{SmF})^{229}$ are popular techniques for achieving enhanced synthesis or secretion of cellulases in microbial strains.

\section{CONCLUSION}

An overwhelming demand for natural products has elevated the significance of industrial enzymes; among which, cellulases occupy a pivotal position. In the environment, microbes (i.e., fungi and bacteria) are essential for the deconstruction of complex carbohydrates (e.g., cellulose). The most actively investigated application of cellulase is the production of biofuels, especially bioethanol, from lignocellulosic biomass like rice straw. Cellulases actively convert cellulosic renewable resources into glucose and other simple fermentable sugars that can be used as substrates for the production of bioethanol. However, the cost of cellulases is a major bottleneck in the economic production of cellulosic ethanol. Several approaches, such as non-culturable cellulolytic microbes, genetic and protein engineering etc., can be employed to achieve economic and industrial dividends.

\section{REFERENCES}

1 M. Dashtban, H. Schraft and W. Qin, IJBS, 5, 578 (2009), https://doi.org/10.7150/iijbs.5.578

2 G. Garrote, H. Dominguez and J. C. Parajo, Food. Eng. J., 52, $211 \quad$ (2001), https://doi.org/10.1016/s0260-8774(01)00108-X

3 S. Sajith, P. Priji, S. Sreedevi and S. Benjamin, J. Nutr. Food Sci., 6, 1 (2016), https://doi.org/10.1186/1743-7075-12-4

4 X. Z. Zhang and Y. H. P. Zhang, "Bioprocessing Technologies in Biorefinery for Sustainable Production of Fuels, Chemicals and Polymers", Wiley, Hoboken, 2013, p. 131

5 G. Yao, R. Wu, Q. Kan, L. Gao, M. Liu et al., Biotechnol. Biofuels, 9, 78 (2016), https://doi.org/10.1186/s13068-016-0491-4

6 Y. Sun and J. Cheng, Bioresour. Technol., 83, 1 (2002), https://doi.org/10.1016/S09608524(01)00212-7

7 D. F. Silva, A. F. A. Carvalho, T. Y. Shinya, G. S. Mazali, R. D. Herculano et al., Enzym. Res., 2017, 1

(2017), https://doi.org/10.1155/2017/4362704

8 D. Ciolacu and V. I. Popa, "Cellulose Allomorphs: Structure, Accessibility and 
Reactivity", Nova Science Publishers Inc., United States, 2010, p. 43

9 A. Payen, C. R. Acad. Sci., 7, 1052 (1838)

10 C. F. Schönbein, Annalen Der Physik, 143

(1846), https://doi.org/10.1002/and p.18461430111

11 E. Schweizer, J. Prakt. Chem., 72, 109 (1856), http://dingler.culture.hu-

berlin.de/article/pj146/ar146090

12 E. Schweizer, J. Prakt. Chem., 67, 430 (1857)

13 E. Schweizer, J. Prakt. Chem., 76, 344 (1859)

14 P. Schützenberger, Bull. Soc. Chim., 4, 176 (1865)

15 P. Schützenberger, Compt. Rendus., 61, 485 (1865)

16 H. Staudinger, Ber Dtsch Chem. Ges., 53, 1073

(1920), https://doi.org/10.1039/C9PY90161B

17 H. Staudinger, "Die hochmolekularen organischen Verbinudungen. Kautschuck und Cellulose", Springer Verlag, Berlin, Nachdruck, 1961 (1932)

18 H. Staudinger and G. Daumiller, Ann. Chem., 529, $219 \quad$ (1937), https://doi.org/10.1002/jlac.1937590115

19 D. N. S. Hon, "Chemical Modification of Lignocellulosic Materials", Marcel Dekker, Inc., New York, 1996, p. 11, https://doi.org/10.1201/9781315139142

20 X. Zogai, N. Nimtz, M. Rodhe, W. Bokranzl and U. Romhng, Mol. Microbiol., 39, 1452 (2001), https://doi.org/10.1046/j.1365-2958.2001.02337.x

21 D. Nobles, D. Romanovicz and R. M. Brown Jr., Plant Physiol., 127, $529 \quad$ (2001), https://doi.org/10.1104/pp.010557

22 R. M. Brown Jr., Pure Appl. Chem., 10, 345 (1996),

https://doi.org/10.1080/10601329608014912S

23 S. Kimura and T. Itoh, Protoplasma, 186, 24 (1995), https://doi.org/10.1007/BF01882023

24 F. H. Isikgor and C. R. Becer, Polym. Chem., 6, 4497 (2015), https://doi.org/10.1039/C5PY00263J

25 M. P. Robbins, G. Evans and J. Valentine, Prog. Energ. Combust. Sci., 38, $138 \quad$ (2012), https://doi.org/10.1016/j.pecs.2011.08.001

26 J. S. Van Dyk and B. I. Pletschke, Biotechnol. $A d v ., \quad 30, \quad 1458 \quad$ (2012), https://doi.org/10.1016/j.biotechadv.2012.03.002

27 J. Kaur, M. S. Taggar, G. S. Kocher and J. Mohammed, Indian J. Chem. Technol., 25, 431 (2018),

http://nopr.niscair.res.in/handle/123456789/45476

28 P. Kaur, G. S. Kocher and M. S. Taggar, Environ. Prog. Sustain. Energ., 38, 635 (2018), https://doi.org/10.1002/ep.12954

29 B. C. Saha and M. N. Cotta, J. Biotechnol., 27, 10 (2010),

https://doi.org/10.1016/j.nbt.2009.10.005

30 N. Sarkar, S. K. Ghosh, S. Bannerjee and K. Aikat, Renew. Energ., 37, 19 (2012), https://doi.org/10.1016/j.renene.2011.06.045
31 R. Muktham, S. K. Bhargava, S. Bankupalli and A. S. Ball, J. Sustain. Bioenerg. Sys., 6, 72 (2015), https://doi.org/10.4236/jsbs.2016.63008

32 M. Packiam, K. Subburamu, R. Desikan, S. Uthandi, M. Subramanian et al., Appl. Environ. Microbiol., $\quad$ 6, $\quad 51 \quad$ (2018), https://doi.org/10.12691/jaem-6-2-4

33 R. Kumar, G Mago, V Balan and C. E. Wyman, Bioresour. Technol., 100, 3948 (2009), https://doi.org/10.1016/j.biortech.2009.01.075

34 S. S. Toor, L. Rosendahl and A. Rudolf, Energy, 36, $2328 \quad$ (2011), https://doi.org/10.1016/j.energy.2011.03.013

35 D. A. N. Ussiri and L. Rattan, Biofuels, 5, 741 (2015),

https://doi.org/10.1080/17597269.2015.1024388

36 Q. Kang, L. Appels, T. Tan and R. Dewil, Sci. World J., 2014, ID $298153 \quad$ (2014), http://dx.doi.org/10.1155/2014/298153

37 Z. Wen, W. Liao and S. Chen, Bioresour. Technol., $\quad 91, \quad 31 \quad$ (2004), https://doi.org/10.1016/s0960-8524(03)00166-4 38 S. M. Read and T. Bacic, Science, 295, 59 (2002), https://doi.org/10.1126/science.1068155

39 Y. Nishiyama, P. Langan and H. Chanzy, J. Am. Chem. Soc., 124, $9074 \quad$ (2002), https://doi.org/10.1021/ja0257319

${ }^{40}$ R. H. Marchessault and P. R. Sundararajan, "The Polysaccharides", edited by G. O. Aspinall, Academic Press, Inc., New York, NY,1993, p. 11

41 R. H. Marchessault and J. A. Howsmon, Textile Res. J., 27, $30 \quad$ (1957), https://doi.org/10.1177/004051755702700105

42 J. E. Stone, A. M. Scallan, E. Donefer and E. Ahlgren, Adv. Chem. Ser., 95, 219 (1969), https://doi.org/10.1021/ba-1969-0095.ch013

43 B. Henrissat, Biochem. J., 2800, 309 (1991), https://doi.org/10.1042/bj2800309

44 L. R. Lynd, P. J. Weimer, W. H. Van Zyl and I. S. Pretorius, Microbiol. Mol. Biol. Rev., 66, 506 (2002), https://doi.org/10.1128/MMBR.66.3.506577.2002

45 D. B. Wilson, Ann. N. Y. Acad. Sci., 1125, 289 (2008), https://doi.org/10.1196/annals.1419.026

46 E. A. Bayer, Y. Shoham and R. Lamed, "The Prokaryotes", edited by M. Dworkin, S. Falkow, E. Rosenberg, K. H. Schleifer and E. Stackebrandt, Springer, New York, NY, 2006, p. 578

C. M. Payne, M. G. Resch, L. Chen, M. F. Crowley, M. E. Himmel et al., Proc. Natl. Acad. Sci. USA, 110, 14646 (2013)

$48 \mathrm{http}: / /$ www.cazy.org/GlycosideHydrolases.html; accessed on 15.07.2019

49 G. Carrard, A. Koivula, H. Soderlund and P. Beguin, Proc. Natl. Acad. Sci. USA, 97, 10342 (2000), https://doi.org/10.1073/pnas.160216697

50 C. Divne, J. Stahlberg, T. T. Teeri and T. A. Jones, J. Mol. Biol., 275, 309 (1998), https://doi.org/10.1006/jmbi.1997.1437 
51 E. A. Bayer, J. P. Belaich, Y. Shoham and R. Lamed, Annu. Rev. Microbiol., 58, 521 (2004), https://doi.org/10.1146/annurev.micro.57.030502.0 91022

52 S. N. Chinedu, V. Okochi, H. Smith and O. Omidiji, Int. J. Biomed. Health Sci., 1, (2005), http://eprints.covenantuniversity.edu.ng/id/eprint/64 53 G. A. Youssef, Afric. J. Microbiol. Res., 5, 1311 (2011), https://doi.org/10.5897/AJMR11.164

54 B. L. Cantarel, P. M. Coutinho, C. Rancurel, T. Bernard, V. Lombard et al., Nucleic Acids Res., 37, 233 (2009), https://doi.org/10.1093/nar/gkn663

A. B. Boraston, B. W. McLean, G. Chen, A. Li, R. A. Warren et al., Mol. Microbiol., 43, 187 (2002), https://doi.org/10.1042/BJ20040892

56 J. Tormo, EMBO J., 15, 5739 (1996), https://doi.org/10.1196/annals.1419.026

57 A. B. Boraston, D. N. Bolam, H. J. Gilbert and G. J. Davies, Biochem. J., 382, 769 (2004), https://doi.org/10.1042/BJ20040892

58 D. W. Abbott, J. M. Eirin-Lopez and A. B. Boraston, Mol. Biol. Evol., 25, 155 (2008), https://doi.org/10.1093/molbev/msm243

59 D. Gao, S. P. S. Chundawat, A. Sethi, V. Balan, S. Gnanakaran et al., Proc. Natl. Acad. Sci. USA, 110, 10922

(2013),

https://doi.org/10.1073/pnas.1213426110

60 A. Gupta and J. P. Verma, Renew. Sust. Energ. Rev., $\quad 41, \quad 550 \quad$ (2015), https://doi.org/10.1016/j.rser.2014.08.032

${ }_{61}$ Y. Li and D. B. Wilson, Biotechnol. Bioeng., 100, 644 (2008), https://doi.org/10.1002/bit.21808

62 A. Magrey, S. Sahay and R. Gothalwal, Int. J. Recent Trends Sci. Technol., 2018, 17 (2018)

63 X. Z. Zhang and Y. H. P. Zhang, "Bioprocessing Technologies in Biorefinery for Sustainable Production of Fuels, Chemicals and Polymers", Wiley, Hoboken, 2013, p. 131

64 M. E. Himmel, Q. Xu, Y. Luo, S. Y. Ding, R. Lamed et al., Biofuels, 1, 323 (2010), https://doi.org/10.4155/bfs.09.25

65 E. A. Bayer, Y. Shoham and R. Lamed, "Prokaryotic Physiology and Biochemistry Rosenberg", edited by E. F. DeLong, S. Lory, E. Stackebrandt and F. Thomson, Springer, New York NY, 2013, p. 215

66 E. A. Bayer, R. Kenig and R. Lamed, J. Bacteriol., 156, 818 (1983)

67 L. Bensoussan, S. Moraïs, B. Dassa, N. Friedman, B. Henrissat et al., Environ. Microbiol., 19, 185 (2016), http://dx.doi. org/10.1111/14622920.13561

68 R. C. Kuhad, R. Gupta and A. Singh, Enzyme Res., 201, 1 (2011), https://doi.org/10.4061/2011/280696

69 Q. Xu, M. G. Resch, K. Podkaminer, S. Yang and J. O. Baker, Sci. Adv., 2, e1501254 (2016), https://doi.org/10.1126/sciadv.1501254

70 S. Pagès, A. Bélaïch, H. P. Fierobe, C. Tardif, C. Gaudin et al., J. Bacteriol., 18, 1801 (1999)
71 O. Shoseyov, M. Takagi, M. A. Goldstein and R. H. Doi, Proc. Natl. Acad. Sci. USA, 89, 3483 (1992), https://doi.org/10.1073/pnas.89.8.3483

72 M. Pohlschröder, S. B. Leschine and E. CanaleParola, J. Bacteriol., 176, 70 (1994), https://doi.org/10.1128/jb.176.1.70-76.1994

73 X. Ze, S. H. Duncan, P. Louis and H. J. Flint, $\begin{array}{lllll}\text { ISME } & J ., & \mathbf{6} & 1535 & \text { (2012), }\end{array}$ https://doi.org/10.1038/ismej.2012.4

74 X. Ze, B. Y. David, J. A. Laverde-Gomez, B. Dassa, P. O. Sheridan et al., MBio, 6, e01058 (2015), https://doi.org/10.1128/mBio.01058-15

75 S. P. Gilmore, J. K. Henske and M. O'Malley Bioengineered, 6, $204 \quad$ (2015), https://doi.org/10.1080/21655979.2015.1060379

76 D. J. Saul, L. C. Williams, R. A. Grayling, L. W. Chamley, D. R. Love, et al., Appl. Environ. Microbiol., 56, 3117 (1990)

77 K. H. Jung, K. M. Lee, H. Kim, K. H. Yoon, S. H. Park et al., Biochem. Mol. Biol. Int., 44, 283 (1998), https://doi.org/10.1080/15216549800201302

78 A. Lupas, H. Engelhardt, J. Peters, U. Santarius, S. Volker et al., J. Bacteriol., 176, 1224 (1994), https://doi.org/10.1128/jb.176.5.1224-1233.1994

79 I. Ozdemir, S. E. Blumer-Schuette and R. M. Kelly, Appl. Environ. Microbiol., 78, 768 (2012), https://doi.org/10.1128/AEM.07031-11

80 S. Moraïs, E. Morag, Y. Barak, D. Goldman, Y. Hadar et al., MBio, 3, e00508 (2012), https://doi.org/10.1128/mBio.00233-11

${ }^{81}$ Y. Vazana, S. Moraïs, Y. Barak, R. Lamed and E. A. Bayer, Methods Enzymol., 510, 429 (2012), https://doi.org/10.1016/B978-0-12-415931-

0.00023-9

${ }^{82}$ S. Y. Ding, Q. Xu, M. Crowley, Y. Zeng, M. Nimlos et al., Curr. Opin. Biotechnol., 19, 218 (2008),

https://doi.org/10.1016/j.copbio.2008.04.008

${ }^{83}$ Y. Vazana, Y. Barak, T. Unger, Y. Peleg, M. Shamshoum et al., Biotechnol. Biofuels, 6, 82 (2013), https://doi.org/10.1186/1754-6834-6-182

84 J. Stern, S. Moraïs, R. Lamed and E. A. Bayer, MBio., 7, $\quad$ e00083 (2016), https://doi.org/10.1128/mBio.00083-16

85 A. Kahn, S. Moraïs, A. P. Galanopoulou, D. Chung, N. S. Sarai et al., Biotechnol. Biofuels, 12, 44 (2019), https://doi.org/10.1186/s13068-0191386-y

86 L. Artzi, B. Dassa, I. Borovok, M. Shamshoum, R. Lamed et al., Biotechnol. Biofuels, 7, 100 (2014), https://doi.org/10.1186/1754-6834-7-100

87 R. H. Doi and A. Kosugi, Nat. Rev. Microbiol., 2, 541 (2004), https://doi.org/10.1038/nrmicro925

${ }^{88}$ J. M. Yarbrough, R. Zhang, A. Mittal, T.V. Wall, Y. J. Bomble et al., ACS Nano, 11, 3101 (2017), https://doi.org/10.1021/acsnano.7b00086

${ }^{89}$ F. Stutzenberger, "Bacterial Cellulase", edited by W. M. Forgartry and C. T. Kelly, $2^{\text {nd }}$ ed., Elseiver Applied Science, London, 1990, p. 37 
90 L. G. Ljungdahl and K. E. Ericksson, $A d v$. Microb. Ecol., 8, $237 \quad$ (1985), https://doi.org/10.1007/978-1-4615-9412-3_6

91 R. M. Gulve and A. M. Deshmukh, Recent Res. Sci. Technol., $\quad 3, \quad 80 \quad$ (2011), https://doi.org/10.1016/j.jgeb.2016.12.001

92 R. K. Rathnan and M. Ambili, Aus. J. Basic Appl. Sci., 5, $1114 \quad$ (2011), http://www.insipub.com/ajbas/2011/Dec

93 M. F. Eida, T. Nagaoka, J. Wasaki and K. Kouno, Microbes Environ., 27, 226 (2012), https://doi.org/10.1264/jsme2.ME11299

94 A. Lykidis, K. Mavromatis, N. Ivanova, I. L. Anderson, M. DiBartolo et al., J. Bacteriol., 189, 2477 (2007), https://doi.org/10.1128/JB.01899-06

95 M. P. Coughlan and F. Mayer, "The Prokaryotes", edited by A. Balowes, H. Trurer, M. Dworkin, W. Harder and K. H. Schleifer, $2^{\text {nd }}$ ed., Springer-Verlag, 1992, p. 460

96 N. Dhillon, S. Chhibber, M. Saxena, S. Pajni and D. V. Vadehra, Biotech. Lett., 7, 695 (1985), https://doi.org/10.1007/BF01040212

97 D. L. Distel, W. Morrill, N. MacLarenToussaint, D. Franks and J. Waterbury, Int. J. Syst. Evol. Microbiol., 52, $2261 \quad$ (2002), https://doi.org/10.1007/BF01040212

98 L. E. Taylor, B. Henrissat, P. M. Coutinho, N. A. Ekborg, S.W. Hutcheson et al., J. Bacteriol., 188 , 3849

(2006),

https://doi.org/10.1128/JB.01348-05

99 R. M. Weiner, L. E. Taylor, B. Henrissat, L. Hauser, P. M. Coutinho et al., PLoS Genet., 4, e1000087

https://doi.org/10.1371/journal.pgen.1000087 (2008),

${ }^{100}$ C. Alexopoulos, C. Mims and M. Blackwell, "Introductory Mycology", New York, John Wiley, 1996, pp. 869

${ }^{101}$ M. Imran, Z. Anwar, M. Irshad, M. J. Asad and H. Ashfaq, Adv. Enzyme Res., 4, 44 (2016), http://dx.doi.org/10.4236/aer.2016.42005

${ }^{102}$ H. Fatma, A. El-Zaher and M. Fadel, New York $\begin{array}{lllll}\text { Sci. } & \text { J., } & \mathbf{3}, & 72 & \text { (2010), }\end{array}$ http://www.sciencepub.net/newyork

${ }^{103}$ R. Mehrotra and K. Aneja, "An Introduction to Mycology”, New Age International, New Delhi, 1990

${ }^{104}$ R. R. Singhania, R. K. Sukumaran, A. Pillai, P. Prema and G. Szakacs, Indian J. Biotechnol., 5, 332 (2006), http://hdl.handle.net/123456789/5592

105 P. Saranraj, D. Stella and D. Reetha, Int. J. Biochem. Biotech. Sci., 1, 1 (2012)

${ }^{106}$ R. K. Sukumaran, R. R. Singhania and A. Pandey, JSIR, 64, $832 \quad$ (2005), https://doi.org/10.4061/2011/280696

107 C. R. Stasek, in "Chemical Zoology, Molluscs", edited by M. Florkin and B. T. Sheer, Academic Press New York and London, 1972, pp. 1-44

108 A. M. Cardoso, J. J. Cavalcante, M. E. Cantão, C. E. Thompson, R. B. Flatschart et al., PLoS ONE,
7 e48505 (2012), https://doi.org/10.1371/journal.pone.0048505

${ }^{109}$ E. Devillard, D. B. Goodheart, S. K. Karnati, E. A. Bayer, R. Lamed et al., J. Bacteriol., 186, 136 (2004), https://doi.org/10.1128/jb.186.1.136145.2004

${ }^{110}$ I. Cann, R. C. Bernardi and R. I. Mackie, Environ. Microbiol., 18, $307 \quad$ (2016), https://doi.org/10.1111/1462-2920.13152

111 A. M. Cardoso, J. J. Cavalcante, R. P. Vieira, J. L. Lima, M. A. Grieco et al., PLoS ON E, 7, e33440 (2012), https://doi.org/10.1371/journal.pone.0033440

${ }^{112}$ G. L. Pinheiro, R. F. Correa, R. S. Cunha, A. M. Cardoso, C. Chaia et al., Front. Microbiol., 6, 860 (2015), https://doi.org/10.3389/fmicb.2015.00860

${ }^{113}$ K. D. Pawar, M. A. Dar, B. P. Rajput and G. J. Kulkarni, Appl. Biochem. Biotech., 175, 1971 (2015), https://doi.org/10.1007/s12010-014-1379-z

${ }_{114}$ S. Chatterjee, S. Sharma, R. K. Prasad, S. Datta, D. Dubey et al., "Recent Advances in Biodegradation, Sanitation and Bioremediation", edited by S. Chatterjee, S. K. Meghvansi, V. Veer, vol. 5 , p. 304

115 J. D. Willis, C. Oppert and J. L. Jurat-Fuentes, Insect Sci., 17, $184 \quad$ (2010), https://doi.org/10.1111/j.1744-7917.2010.01322.x

${ }^{116}$ L. J. Wong, P. S. H'ng, S. Y. Wong, S. H. Lee, W. C. Lum et al., Pak. J. Biol. Sci., 17, 956 (2014), https://doi.org/10.3923/pjbs.2014.956.963

117 A. Brune, in "Encyclopedia of Insects", edited by V. H. Resh and R. T. Carde,) $2^{\text {nd }}$ ed., Academic Press, New York, USA, 2009, p. 978

118 M. S. Taggar, J. Appl. Nat. Sci.,7, 625 (2015), https://doi.org/10.31018/jans.v7i2.656

${ }^{119}$ R. Fischer, R. Ostafe and R. M. Twyman, $A d v$. Biochem. Eng. Biotechnol., 136, 51 (2013), https://doi.org/10.1007/10_2013_206

${ }^{120}$ X. Zhou, J. A. Smith, F. M. Oi, P. G. Koehler, G. W. Bennett et al., Gene, 395, 29 (2007), https://doi.org/10.1016/j.gene.2007.01.004

${ }^{121}$ S. M. Geib, M. Tien and K. Hoover, Insect Sci., 17, 253 (2010), https://doi.org/10.1111/j.17447917.2010.01323.x

122 A. H. Ferreira, S. R. Marana, W. R. Terra and C. Ferreira, Insect. Biochem. Mol. Biol., 31, 1065 (2001), https://doi.org/10.1016/s09651748(01)00054-6

${ }^{123}$ A. E. Cazemier, H. J. M. Op den Camp, J. H. P. Hackstein, G. D. Vogels, Comp. Biochem. Physiol., 118 101

(1997),

https://doi.org/10.1023/A:1023325817663

${ }^{124}$ M. Wenzel, I. Schonig, M. Berchtold, P. Kampfer and H. J. Konig, Appl. Microbiol., 92, 32 (2002), https://doi.org/10.1046/j.13652672.2002.01502.x

${ }^{125}$ N. Chakraborty, G. M. Sarkar and S. C. Lahiri, Environmentalist, $20, \quad 9 \quad$ (2000), https://doi.org/10.1023/A:1006691524607 
126 D. M. Cook and J. Doran-Peterson, Insect Sci., 17, 303 (2010), https://doi.org/10.1111/j.17447917.2010.01343.x

${ }^{127}$ I. Delalibera, J. Handelsman and K. F. Raffa, Environ. Entomol., 34, 541 (2005), https://doi.org/10.1603/0046-225X-34.3.541

128 A. E. Cazemier, J. C. Verdoes, F. A. Reubsaet, J. H. Hackstein, C. van der Drift et al., Antonie Van Leeuwenhoek, 83, $135 \quad$ (2003), https://doi.org/10.1023/A:1023325817663

${ }^{129}$ O. Blifernez-Klassen, V. Klassen, A. Doebbe, K. Kersting, P. Grimm et al., Nat. Commun., 3, 1214 (2012), https://doi.org/10.1038/ncomms 2210

130 A. Davison and M. Blaxter, Mol. Biol. Evol., 22, 1273

https://doi.org/10.1093/molbev/msi107

(2005),

${ }^{131}$ G. I. D. Guerriero, K. Sergeant, S. Legay, J. F. Hausman, H. M. Cauchie et al., Int. J. Mol. Sci., 19, 1782 (2018), https://doi.org/ 10.3390/ijms19061782 132 A. Wahyudi, M. N. Cahyanto, M. Soejono and Z. Bachruddin, J. Indonesian Trop. Anim. Agric., 35, 34

(2010),

https://doi.org/10.14710/jitaa.35.1.34-41

${ }^{133}$ J. Miron, D. B. Ghedalia and M. Morisson, Int. J. Dairy Sci. Process, 84, 1294 (2001), https://doi.org/10.3168/jds.S0022-0302(01)70159-2 ${ }^{134}$ D. N. Kamra, Curr. Sci., 89, 122 (2005), https://www.jstor.org/stable/24110438

135 J. B. Russell, R. E. Muck and P. J. Weimer, FEMS Microbiol. Ecol., 67, 183 (2009), https://doi.org/10.1111/j.1574-6941.2008.00633.x

${ }^{136}$ P. Gupta, K. Samant and A. Sahu, Int. J. Microbiol. Res., 2012, 1 (2012), http://dx.doi.org/10.18576/jehe/060103

137 J. L. Morgan, J. Strumillo and J. Zimmer, Nature, $\quad 493, \quad 181 \quad$ (2013), https://doi.org/10.1038/nature11744

${ }^{138}$ S. Safika, P. Aditiawati and A. Akhmaloka, J. Pure Appl. Microbiol., 7, 269 (2013)

139 S. Singh, V. S. Moholkar and A. Goyal, ISRN Microbiol., $\quad \mathbf{2 0 1 3}, \quad 1 \quad$ (2013), https://doi.org/10.1155/2013/728134

${ }^{140}$ B. V. Mohite and S. V. Patil, Carbohyd. Polym., 106, 132 (2014),

https://doi.org/10.1016/j.carbpol.2014.02.012

${ }^{141}$ C. Moon, D. Gagic, M. Ciric, S. Noel, E. Summers et al., Proc. 5 Australian Dairy Sci. Symp., $\quad \mathbf{2 0 1 4}, \quad 377 \quad$ (2014), https://hdl.handle.net/10289/11169

${ }^{142}$ D. C. Li, A. N. Li and A. C. Papageorgiou, Enzyme Res., 2011, 1 (2011), https://doi.org/10.1007/978-3-030-19030-9_20

${ }^{143}$ P. Murray, N. Aro, C. Collins, A. Grassick and M. Penttilä PEP, 38, 248 (2004), https://doi.org/10.1016/j.pep.2004.08.006

${ }^{144}$ Z. Fangdong, J. Anhui Agric. Sci., 36, 6171 (2008), https://doi.org/10.21315/tlsr2019.30.1.8

${ }^{145}$ S. Acharya and A. Chaudhary, J. Sci. Ind. Res., 70, 142

(2011),
146 S. Ando, H. Ishida, Y. Kosugi and K. Ishikawa, Appl. Environ. Microbiol., 68, 430 (2002), https://doi.org/10.1128/aem.68.1.430-433.2002

147 W. Grogan, Appl. Environ. Microbiol., 57, 1644 (1991), https://doi.org/10.1155/2015/978632

${ }^{148}$ K. Bronnenmeier, A. Kern, W. Libel and W. Staudenbauer, Appl. Environ. Microbiol., 61, 1399 (1995)

${ }^{149}$ L. Ruthersmith and R. Daniel, Biochem. J., 277, 887 (1991), https://doi.org/10.1042/bj2770887

${ }^{150}$ V. Zverlov, K. Riedel and K. Bronnenmeier, Microbiology, $\quad \mathbf{1 4 4}, \quad 457 \quad$ (1998), https://doi.org/10.1099/00221287-144-2-457

${ }^{151}$ C. A. Parveen, D. Archana, G. Gunajit, B. Madhumita and B. R. Chandra, Int. J. Microbiol. Res., 8, 776 (2016)

${ }^{152}$ L. Potprommanee, X. Q. Wang, Y. J. Han, D. Nyobe, Y. P. Peng et al., Plos One, 12, e0175004 (2017),

https://doi.org/10.1371/journal.pone.0175004

${ }^{153}$ E. Kalogeris, P. Christakopoulos, P. Katapodis, A. Alexiou, S. Vlachou et al., Process Biochem., 38, 1099 (2003), https://doi.org/10.1016/S00329592(02)00242-X

154 K. M. Borkar, Int. J. Life Sci., 6, 55 (2016), http://oaji.net/articles/2016/736-1463304460.pdf

${ }^{155}$ P. L. N. Reddy, B. S. Babu, A. Radhaiah and A. Sreeramulu, Int. J. Curr. Microbiol. Appl. Sci., 3, $761 \quad$ (2014), http://www.ijcmas.com/vol-37/P.Laksh

${ }^{156}$ S. Sajith, S. Sreedevi, P. Priji and S. Benjamin, Ann. Microbiol., 64, $763 \quad$ (2014), https://doi.org/10.4172/2155-9600.1000461

157 G. S. Kocher, K. L. Kalra and G. Banta, Internet

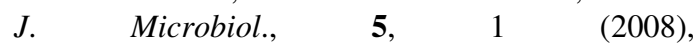
https://doi.org/10.5580/1658

${ }^{158} \mathrm{X}$. Liming and S. Xueliang, Bioresour. Technol., $\quad 91, \quad 259 \quad$ (2004), https://doi.org/10.1016/s0960-8524(03)00195-0

159 D. Liu, R. Zhang, X. Yang, Z. Zhang, S. Song et al., Microbial Cell Fact., 11, 25 (2012), https://doi.org/10.1186/1475-2859-11-25

${ }^{160}$ Y. H. Liang, Z. Zhang, M. Wu, Y. Wu and J. X. Feng, Bio. Med. Res. Int., 2014, 1 (2014), https://doi.org/10.1155/2014/512497

${ }^{161}$ S. Sethi, A. Datta, B. L. Gupta and S. Gupta ISRN Biotech., 2013, 1 (2013), http://dx.doi.org/10.5402/2013/985685

${ }^{162}$ L. J. Yin, P. S. Huang and H. H Lin, J. Agric. Food Chem., 58, 9833 (2010), https://doi.org/10.1021/jf1019104

${ }^{163}$ S. Sadhu, P. Saha, S. K. Sen, S. Mayilraj and T. K. Maiti, SpringerPlus, 2, $10 \quad$ (2013), https://doi.org/10.1186/2193-1801-2-10

164 P. Vijayaraghavan and S. G. P. Vincent, Pol. J. Microbiol., 61, 51 (2012)

${ }^{165}$ F. Islam and N. Roy, BMC Res. Notes, 11, 445 (2018), https://doi.org/10.1186/s13104-018-3558-4 ${ }^{166}$ X. P. Haung and C. Monk, World J. Microbiol. Biotechnol., $\quad 20, \quad 85 \quad$ (2004), 
https://doi.org/10.1023/B:WIBI.0000013316.12730 .e7

${ }^{167}$ N. P. Listyaningrum, A. Sutrisno and A. K. Wardani, Earth Environ. Sci., 131, 012043 (2018), https://doi.org/10.1088/1755-1315/131/1/012043

168 X. Peng, W. Qiao, S. Mi, X. Jia, H. Su et al., Biotechnol. Biofuels, $8, \quad 131 \quad$ (2015), https://doi.org/10.1186/s13068-015-0313-0

${ }^{169}$ R. Gaur and S. Tiwari, BMC Biotechnol., 15, 19 (2015), doi.org/10.1186/s12896-015-0129-9

170 J. de Cassia Pereira, N. P. Marques, A. Rodrigues, D. B. de Oliveira, M. Boscolo et al., J. Appl. Microbiol., 118, $928 \quad$ (2016), https://doi.org/10.1111/jam.12757

${ }^{171}$ M. M. S. Moretti, D. A. Bocchini-Martins, R. Da Silva, A. Rodrigues, L. D. Sette et al., Brazilian J. $\quad$ Microbiol., $\quad \mathbf{4 3} \quad$ (2012), https://doi.org/10.1590/S151783822012000300032

${ }^{172}$ P. Saroj, P. Manasa and K. Narasimhulu, Bioresour. Bioprocess., 5, $31 \quad$ (2018), https://doi.org/10.1186/s40643-018-0216-6

${ }^{173}$ V. N. Thanh, N. T. Thuy, H. T. T. Houng, D. D. Hien, D. T. M. H. Hang et al., Sci. Rep., 9, 3674 (2019), https://doi.org/10.1038/s41598-019-402135

${ }^{174}$ V. Ventorino, E. Ionata, L. Birolo, S. Montella and L. Marcolongo, Front. Microbiol., 7, 2061 (2016), https://doi.org/10.3389/fmicb.2016.02061

175 N. A. El-Sersy, H. Abd-Elnaby, G. M. AbouElela, H. A. H. Ibrahim and N. M. K. El-Toukhy, Afr. J. Biotechnol., 9, $6355 \quad$ (2010), http://www.academicjournals.org/AJB

${ }^{176}$ E. N. Fatokun, U. U. Nwodo and A. I. Okoh, Appl. Sci., 6, $286 \quad$ (2016), https://doi.org/10.3390/app6100286

177 A. Amore, O. Pepe, V. Ventorino, L. Birolo, C. Giangrande et al., Microb. Cell Fact., 11, 164 (2012), https://doi.org/10.3390/app6100286

${ }^{178}$ M. A. M. Yassien, A. A. M. Jiman-Fatani and H. Z. Asfour, Afr. J. Microbiol. Res., 8, 348 (2014), https://doi.org/10.5897/AJMR2013.6500

${ }^{179}$ R. Chandra, H. Takeuchi, T. Hasegawa and R. Kumar, Energy, 43, $27 \quad$ (2012), https://doi.org/10.1016/j.energy.2012.04.029

${ }^{180}$ P. Binod, R. Sindhu, R. R. Singhania, S. Vikram, L. Devi et al., Bioresour. Technol., 101, 4767 (2010), https://doi.org/10.1016/j.biortech.2009.10.079

${ }^{181}$ M. Takano and K. Hoshino, Bioresour.

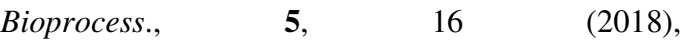
https://doi.org/10.1186/s40643-018-0203-y

${ }^{182}$ K. Robak and M. Balcerek, Food Technol. Biotechnol., $\quad 56, \quad 174 \quad$ (2018), https://doi.org/10.17113/ftb.56.02.18.5428

${ }^{183}$ C. E. Wyman, V. Balan and B. E. Dale, Bioresour. Technol., 102, 11052 (2011), https://doi.org/10.1016/j.biortech.2011.06.069

${ }^{184}$ Global ethanol production by country, https://ethanolrfa.org/wp-
content/uploads/2019/02/RFA2019 Outlook.pdf; Accessed on 16.07.2019

${ }^{185} \mathrm{https} / / /$ bioenergyinternational.com/marketsfinance/us-tops-as-number-one-ethanol-producerconsumer-and-exporter; accessed on 16.07.2019

186 A. Demirbas, Appl. Energ., 88, 17 (2011), https://doi.org/10.1016/j.apenergy.2010.07.016 ${ }^{187}$ L. Podkuiko, K. Ritslaid, J. Olt and T. Kikas, Agron. Res., 12, $373 \quad$ (2014), https://doi.org/10.3176/proc.2017.2.03

${ }^{188}$ T. Kikas, M. Tutt, M. Raud, M. Alaru, R. Lauk et al., Int. J. Green Energ., 13, 49 (2016), https://doi.org/10.1080/15435075.2014.909359

${ }^{189}$ G. S. Kocher, P. Kaur and M. S. Taggar, Curr. Biochem. Eng., 4, $151 \quad$ (2017), https://doi.org/10.2174/2212711903666161102141 859

${ }^{190}$ M. Koller, A. Salerno, P. Tuffner, M. Koinigg, H. Böchzelt et al., J. Clean Prod., 37, 377 (2012), https://doi.org/10.1016/j.jclepro.2012.07.044

${ }^{191}$ E. M. Aro, Ambio, 45, 24 (2016), https://doi.org/10.1007/s13280-015-0730-0

${ }^{192}$ Food and Agriculture Organization of the United Nations, Rice Market Monitor, FAO, Washington, DC (2017)

193 W. Wang, X. Wu, A. Chen, X. Xie, Y. Wang et al., Sci. Rep., 6, $37402 \quad$ (2016), https://doi.org/10.1038/srep37402

${ }^{194}$ P. S. Rezael, G. O. Najafpour, H. Shafaghati and S. Mahjoub, World Appl. Sci. J., 7, 306 (2009), https://doi.org/10.3389/fpls.2016.00639

${ }^{195}$ L. Wang, M. Yang, X. Fan, X. Zhu, T. Xu et al., Process Biochem., 46, $1619 \quad$ (2011), https://doi.org/10.1016/j.procbio.2011.05.004

${ }^{196}$ Z. H. Liu, L. Qin, J. Q. Zhu, B. Z. Li and Y. J. Yuan, Biotechnol. Biofuels, 7, 167 (2014), https://doi.org/10.1186/ s13068-014-0167-x ${ }^{197}$ S. Jin and H Chen, Biochem. Eng. J., 30, 225 (2006), https://doi.org/10,1016/j.bej.2006.05.002

${ }^{198}$ S. Marx, B. Ndaba, I. Chiyanzu and C. Schabort, Biomass Bioenerg., 65, 145 (2014), https://doi.org/10.1016/J.BIOMBIOE.2013.11.019

199 M. Gáspár, G. Kálmán and K. Réczey, Process Biochem., $\quad 42, \quad 1135 \quad$ (2007), https://doi.org/10.1016/j.procbio.2007.04.003

${ }^{200}$ T. H. Kim and Y. Y. Lee, Appl. Biochem. Biotechnol., $\quad 137, \quad 81 \quad$ (2007), https://doi.org/10.1007/s12010-007-9041-7

${ }^{201}$ M. Lopez-Abelairas, M. Alvarez Pallin, D. Salvachua, T. Lu-Chau, M. J. Martinez et al., Bioprocess Biosyst. Eng., 36, 1251 (2013), https://doi.org/10.1007/s00449-012-0869-z

${ }^{202}$ S. B. Kim, S. J. Lee, J. H. Lee, Y. R. Jung, L. P. Thapa et al., Biotechnol. Biofuels, 6, 9 (2013), https://doi.org/10.1186/1754-6834-6-109

${ }^{203}$ S. Zhu, Y. Wu, Z. Yu, X. Zhang, C. Wang et al., Process Biochem., 41, 869 (2005), https://doi.org/10.1016/j.procbio.2005.03.016 


\section{PARDEEP KAUR et al.}

204 C. Y. Yang and T. J. Fang, Bioresour. Technol., 164 , 198

(2014),

https://doi.org/10.1016/j.biortech.2014.05.004

${ }^{205}$ R. R. Singhania, A. K. Patel, C. R. Soccol and A. Pandey, Biochem. Eng. J., 44, 13 (2009), https://doi.org/10.1016/j.bej.2008.10.019

${ }^{206}$ D. Singla, M.S. Taggar, G.S. Kocher and A. Kalia, Cellulose Chem. Technol., 52, 803 (2018), https://www.cellulosechemtechnol.ro/pdf/CCT910(2018)/p.803-813.pdf

${ }^{207}$ T. Kogo, Y. Yoshida, K. Koganei, H. Matsumoto, T. Watanabe et al., Bioresour. Technol., 233, $67 \quad$ (2017), https://doi.org/10.1016/j.biortech.2017.01.075

${ }^{208}$ S. S. H. Sarabana, Middle East J. Agric. Res., 6, 1417

http://www.curresweb.com/mejar/mejar/2017/1417 -1425.pdf

${ }^{209}$ M. Rahnama, S. Mamat, U. K. Md Shah, F. H. Ling, N. A. A. Rahman et al., BioResources, 8, 2881 (2013), http://ncsu.edu/bioresources

${ }^{210}$ M. J. Taherzadeh and C. Niklasson, ACS Symp. Ser., 889, 49 (2004), https://doi.org/10.1021/bk2004-0889.ch003

211 Z. Zhang, B. Liu and Z. K. Zhao, Polym. Degrad. Stabil., 97, $573 \quad$ (2012), https://doi.org/10.1016/j.polymdegradstab.2012.01. 010

${ }^{212}$ A. Kuila, V. Sharma and V. K. Garlapati, $A d v$. Biofeedstocks Biofuels, 1, $85 \quad$ (2016), https://doi.org/10.1002/9781119117322.ch4

${ }^{213}$ N. Rahnama, H. L. Foo, N. A. A. Rahman, A. Ariff and U. K. M. Shah, BMC Biotechnol., 14, 103 (2014), https://doi.org/10.1186/s12896-014-0103-y ${ }^{214}$ C. Pasha, B. C. Shekhar, B. Srinivas, K. Balakrishna and A. Hanumalal, J. Sci. Ind. Res., 71, 616 (2012), http://hdl.handle.net/123456789/14632

${ }^{215}$ L. G. A. Ong, C. H. Chan and A. L. Chew, J.

Med. Bioeng., $1, \quad 14 \quad$ (2012), https://doi.org/10.1016/S0960-8524(96)00169-1

${ }^{216}$ Q. Z. Zhang and W. M. Caia, Biomass Bioenerg., $\quad 32, \quad 1130 \quad$ (2008), https://doi.org/10.1016/j.biombioe.2008.02.006
${ }^{217}$ M. A. Abo-State, A. M. E. Ragab, N. S. ElGendy, L. A. Farahat and H. R. Madian, Sci. Res., 3, 19

(2014), https://doi.org/10.4236/soft.2014.32003

218 P. R. Mohan, B. Ramesh and O. V. S. Reddy, Res. J. Microbiol., 7, 1 (2012), https://doi.org/10.3932/jm.2012.1.12

${ }^{219}$ N. Sarkar and K. Aikat, Int. J. Chem. Eng., https://doi.org/10.1155/2014/959845(2014), https://doi.org/10.1155/2014/959845

${ }^{220}$ N. K. Aggarwal, V. Goyal, A. Saini, A. Yadav and R. Gupta, 3 Biotech., 7, 158 (2017), https://doi.org/10.1007/s13205-017-0755-0

${ }^{221}$ N. Annamalai, M. V. Rajeswari and T. Balasubramanian, Biomass Bioenerg., 68, 151 (2014), https://doi.org/10.1016/j.biombioe.2014.06.018 ${ }^{222}$ A. Singh, S. Namita and N. R. Bishnoi, J. Sci. Ind. Res., 69, $232 \quad$ (2010), http://hdl.handle.net/123456789/7385

${ }^{223}$ J. K. Saini, R. Saini and L. Tewari, 3 Biotech., 5, 337 (2015), https://doi.org/10.1007/s13205-0140246-5

${ }^{224}$ C. Yang, Y. Xia, H. Qu, A. D. Li, R. Liu et al., Biotechnol. Biofuels, 9, $138 \quad$ (2016), https://doi.org/10.1186/s13068-016-0557-3

${ }^{225}$ Y. Ikeda, A. Parashar, M. Chae and D. C. Bressler, J. Thermodyn. Catal., 6, 1 (2015), https://doi.org/10.4172/2157-7544.1000149

${ }^{226}$ J. L. Adrio and A. L. Demain, Bioeng. Bugs., 1, 116 (2010), https://doi.org/10.3390/biom4010117

${ }^{227}$ S. Ellila, L. Fonseca, C. Uchima, J. Cota, G. H. Goldman et al., Biotechnol. Biofuels, 10, 30 (2017), https://doi.org/10.1186/s13068-017-0717-0

${ }^{228}$ M. Maki, K. T. Leung and W. Qin, Int. J. Biol. $\begin{array}{llll}\text { Sci., } & 5, & 550 & \text { (2009), }\end{array}$ https://doi.org/10.7150/ijbs.5.500

${ }^{229}$ Q. Wang, L. Chen, D. Yu, H. Lin, Q. Shen et al., Sci. Total Environ., 609, 3129 (2017), https://doi.org/10.1016/j.scitotenv.2017.07.212 